\title{
Effect of invasive species on the structure and function of the Sylt-Rømø Bight ecosystem, northern Wadden Sea, over three time periods
}

\author{
Dan Baird ${ }^{1, *}$, Harald Asmus ${ }^{2}$, Ragnhild Asmus ${ }^{2}$ \\ ${ }^{1}$ Department of Botany and Zoology, Stellenbosch University, 7600 Stellenbosch, South Africa \\ ${ }^{2}$ Alfred Wegener Institute for Polar and Marine Research, Wattenmeer Station, Station Sylt, 25992 List, Sylt, Germany
}

\begin{abstract}
Three quantitative energy flow models have been constructed for the Sylt-Rømø Bight representing the stocks and flows in the ecosystem during 1995, 2007 and 2010. The 1995 model consists of 59 compartments, while the 2007 and 2010 models have 63 compartments each. The 4 additional compartments in the 2007 and 2010 models are 2 native barnacle species Semibalanus balanoides and Balanus crenatus and 2 invasive species namely the Pacific oyster Crassostrea gigas and the Australasian barnacle Austrominius modestus. Oyster and A. modestus biomass increased from virtually zero in 1995 to 15 and $1.3 \mathrm{gC} \mathrm{m}^{-2}$, respectively, in 2007, and then subsequently decreased to 0.6 and $0.12 \mathrm{gC} \mathrm{m}^{-2}$, respectively, in 2010. Reasons for the increases in oysters and $A$. modestus are related to climate change which favored strong recruitment of the invasive species during unseasonably warm summers, and the subsequent decline to weak recruitment of the invasive species and an unseasonably cold 2009/2010 winter. We used ecological network analysis (ENA) to quantify ecosystem structure and function through analyses of energy (or carbon) transfer between living and non-living compartments in each of the 3 network models. Results from ENA show an increase in most of the system attributes, but a decline in number of cycles, the trophic efficiency, the ascendency ratios, and relative redundancy from 1995 to 2007; these are ascribed to the impact of the invasive species on system organization and function. Following the dramatic decline of the invasive species from 2007 to 2010 most of the system attributes decreased. The variance in the biomass and associated flows of other compartments in addition to that of the invasive species has also played a role in the changes in system attributes and function.
\end{abstract}

KEY WORDS: Ecosystem function - Alternate ecosystem states $\cdot$ Invasive species $\cdot$ Crassostrea gigas · Austrominius modestus · Food web models · Ecological network analysis · Northern Wadden Sea

Resale or republication not permitted without written consent of the publisher

\section{INTRODUCTION}

It is generally accepted that marine ecosystems are not constant but change over time due to their natural variability (e.g. seasons), fluctuating environmental conditions, loss/gain of biodiversity, and anthropogenic inputs (e.g. nutrient loading, pollution). A system may switch from one state to an alternate state under certain conditions, and may switch back to the previous one, a phenomenon known as 'hysteresis' (Scheffer et al. 2001, Baird 2011). Shifts between alternate stable states have been observed in lakes (Scheffer et al. 1997, Carpenter et al. 1999) and coral reefs (Done 1992, Knowlton 1992, McCook 1999), while oceanic regime shifts of large ecosystems are reported by Hare \& Mantus (2000) in the North Pacific Ocean and by Shannon et al. (2004) in the southern Benguela upwelling ecosystem. Very 
often a shift from one state to another is not permanent, so that an ecosystem can shuttle between 2 alternate states. Systems often exhibit different features (in terms of structure and function) between months, seasons, years, and decades (cf. Baird 2011 and references therein), and, whereas these shifts do not necessarily result in alternate stable states, they can revert back to their approximate original state at the beginning of the following time cycle (e.g. seasons, years).

The invasion of alien species in an area or ecosystem where it previously did not occur appears to be a rather common phenomenon globally (Crooks 2002). Invasive species can differ from endemic ones in the use of resources (nutrients, food, space) thus altering energy flow pathways and biomass ratios in food webs of the system (Mack et al. 2000, Baxter et al. 2004), while they are also capable of changing the physical structure of the ecosystem itself (Vitousek et al. 1987, Nehls et al. 2006). Furthermore, species invasions in marine systems can have major effects on the structure and functioning of ecosystems (Vitousek et al. 1987, Crooks 2001, Grosholz 2002, Stachowicz \& Byrnes 2006, Büttger et al. 2008). Although there are numerous reports on the impact of invasive species on ecosystems, few have examined these perceived changes at the ecosystem level in a quantified manner. Miehls et al. (2009) provided an extensive analysis of the impact of the zebra mussel Dreissena polymorpha on the functioning of the Lake Oneida ecosystem, New York, USA, using ecological network analysis (ENA), while Nicholls et al. (2011) observed biological regime shifts in the Bay of Quinte ecosystem (Lake Ontario) in 1995 shortly after the establishment of invasive dreisssenid mussels. Baird (2011) analyzed quantitative food webs of the mussel beds in the Sylt-Rømø Bight by means of ENA to assess the impact of a decline in native suspension feeders (i.e. prey of birds) due to the spread of invasive species, such as the Pacific oyster Crassostrea gigas, on their predators at higher trophic levels. Simulation modeling indicated a decline in bird numbers following the decline in prey abundance due to oyster invasion. Ecosystems may thus undergo state changes when invasive species impact the structure and function of the system.

Reise et al. (1998) reported that approximately 80 non-indigenous species have been introduced in the coastal areas of the North Sea with most of them arriving during the 1970s. Their introduction was mainly through ballast water in transoceanic shipping and aquaculture. It was suggested that the invasive species were rather additive than causing dis- placements or extinctions of native species (Reise et al. 1998), and may not necessarily have strong direct effects on the functioning of recipient ecosystems (Reise et al. 2006). Global warming has been shown to be an important vector enhancing invasions of new species in the Wadden Sea, since most of them originate from warmer oceanic and coastal regions than that of the North Sea (Reise \& van Beusekom 2008). Since the present paper deals mainly with the intertidal ecosystem of the Sylt-Rømø Bight (also called the List Tidal Basin) references to invasive species and ecosystem attributes focus on this region of the bight.

Evidence for an increase in water temperature in the Sylt-Rømø Bight in the northern Wadden Sea is given by Martens \& van Beusekom (2008) where an annual increase of $0.134^{\circ} \mathrm{C} \mathrm{yr}^{-1}$ between 1984 and 2005 has been recorded. Of the introduced species in Wadden Sea ecosystems, the Pacific oyster Crassostrea gigas and the subtidal slipper limpet Crepidula fornicata appear to have been most successful (Nehls et al. 2006). The development and spread of the $C$. gigas population in the northern Wadden Sea, including the bight, was probably facilitated by oyster cultures off the island of Sylt where oyster farms started their business in 1986, and from where larvae dispersed to settle as epibionts on dense intertidal mussel beds where the blue mussel Mytilus edulis occurs in abundance (Diederich et al. 2005). Reise (1998) reported successful reproduction of oysters with strong spatfalls in 1991 and 1994, and the rapid invasion of C. gigas into the German Wadden Sea through larval supply and dispersion (Brandt et al. 2008). High water temperatures during 3 successive summer spawning seasons and mild winters from 2001 to 2003 resulted in successful recruitment, resulting in a massive increase in the oyster population and overgrowth of native ( $M$. edulis) mussel beds (Diederich 2006, Kochmann et al. 2008). On the other hand, $M$. edulis recruitment repeatedly failed, most probably because of higher water temperatures (Kochmann et al. 2008), resulting in a decrease in mussel bed area (Büttger et al. 2008) and in biomass by approximately $60 \%$ between 1998 and 2010 (Büttger et al. 2010). Oyster abundance in the SyltRømø Bight increased from 3.6 ind. $\mathrm{m}^{-2}$ in 1995 to a peak of 1829 ind. $\mathrm{m}^{-2}$ in 2007. Numbers then decreased to 69 ind. $\mathrm{m}^{-2}$ in 2010 (Büttger et al. 2010) due to weak spat fall and recruitment in 2008 and 2009 , and a severely cold winter in 2009/2010. Concomitant with the increase in oyster abundance and biomass, another invasive species, the antipodean cirripede crustacean Austrominius modestus Darwin 
(formerly known as Elminius modestus Darwin), first observed on the shores of the island of Sylt in 1955, increased in abundance so that by 2007 it had overtaken the native barnacles Semibalanus balanoides and Balanus crenatus in abundance (Witte et al. 2010). Further significant changes in the intertidal flats of the North Frisian Wadden Sea are a 3- to 4fold increase in the seagrass bed area (of Zostera spp.) from 1994 to 2006 (Reise \& Kohlus 2008), a concomitant increase of macrophytes in the bight, and a decrease of the macroalgal Fucus vesiculosus cover of mussel beds to about $10 \%$ in 2005 of its highest recorded cover of $95 \%$ in 1999 (Büttger et al. 2008).

The primary objective of the present study is to assess the impact of 2 invasive species (the Pacific oyster Crassostrea gigas and the antipodean cirripede crustacean Austrominius modestus) on the structure and function of the entire intertidal region of the Sylt-Rømø Bight ecosystem. We also consider the decline of prey species such as the blue mussel, the increase in seagrass beds, and temporal changes in the abundance of other native species and communities. To this end 3 quantified network models with carbon (a surrogate for energy) were constructed to represent 3 different time periods of the Sylt-Rømø Bight, respectively, and analyzed using ENA protocols which were developed to holistically assess the complex interactions within an ecosystem (see Fath et al. 2007 and references therein), and which clarify the complex relationships in food webs. The first model represents data collected during the period 1990 to 1995 when invasive species abundance was very low. The second model is based on the data of 2007 when oyster and A. modestus abundance reached its peak, while the third model examines the system after the significant decline in oyster and $A$. modestus abundance and biomass in 2010. The last 2 models also take into account other structural changes such as the increase in seagrass beds, declines in the blue mussel, Fucus vesisiculosus cover, and changes in the abundance of other species and communities in the bight. The output results from network analysis were then used to assess changes in the functioning of the bight ecosystem over time.

The theoretical foundations and the basic concepts of ENA have been adequately described by, for example, Ulanowicz (1986, 2004), Wulff et al. (1989), Fath \& Patten (1999), Fath et al. (2004), Jørgensen \& Fath (2004), while Christian et al. (2005) discussed the role of ENA in the comparative ecology of coastal ecosystems. The software that can run these analyses is readily available (Ulanowicz \& Kay 1991, Christen-

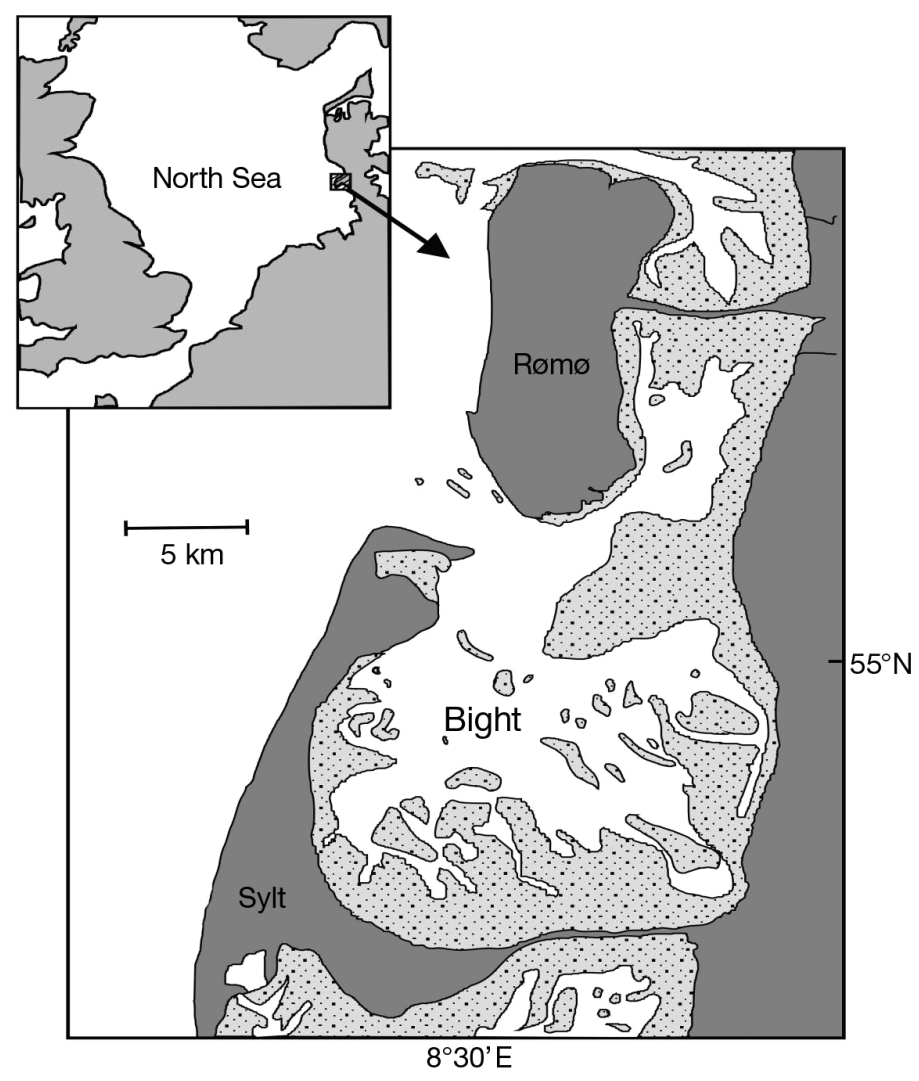

Fig. 1. Location and map of the Sylt-Rømø Bight ecosystem. The intertidal area is indicated in stippled grey

sen \& Pauly 1992, Allesina \& Bondavalli 2004, Fath \& Borret 2006), and can be downloaded from www. glerl.noaa.gov/EcoNetwrk/.

\section{MATERIALS AND METHODS}

\section{Study site}

The Sylt-Rømø Bight $\left(54^{\circ} 52^{\prime}\right.$ to $55^{\circ} 10^{\prime} \mathrm{N}$, and $8^{\circ} 20^{\prime}$ to $8^{\circ} 40^{\prime} \mathrm{E}$ ), also known as the List Tidal Basin, is a semi-enclosed basin between the islands of Sylt, Germany, and Rømø, Denmark, and is connected to the North Sea by a $2.8 \mathrm{~km}$ wide channel (the Lister Tief) between the 2 islands as shown in Fig. 1. The bight forms part of the greater Wadden Sea, a shallow coastal region with a total area of approximately $8935 \mathrm{~km}^{2}$ of the North Sea stretching from the Netherlands to Denmark. The Dutch and German part (about $87 \%$ ) of this large ecosystem was declared a World Heritage Site by UNESCO in July 2009. The surface area of the bight covers about $404 \mathrm{~km}^{2}$ with an intertidal area of about $135 \mathrm{~km}^{2}$. The average water temperature in the bight varies 
from $-1{ }^{\circ} \mathrm{C}$ in winter (October to March) to about $20^{\circ} \mathrm{C}$ in summer (April to September), while the salinity fluctuates between 28 and 32. Little freshwater with a minimal nutrient load is discharged into the bight so that salinity variability is mainly due to precipitation and evaporation. The diurnal tidal prism for the bight is about $550 \times 10^{6} \mathrm{~m}^{3}$, the water residence time in the bight is between 19 and $29 \mathrm{~d}$, while between 8 and $12 \%$ of the bight waters is exchanged per tidal cycle with the contiguous Wadden Sea through the Lister Tief channel (Fast et al. 1999). The tidal prism for the intertidal is approximately $66 \times 10^{6} \mathrm{~m}^{3}$ for the intertidal area (calculated after Gätje \& Reise 1998).

Different plant and animal communities are associated with different habitat types occurring in the intertidal reach of the bight, while the remaining subtidal area of about $268 \mathrm{~km}^{2}$ consists mainly of a sandy substrate. The intertidal region consists of 8 habitat types (or sub-ecosystems); these are identified according to the dominant plant and faunal communities and by their characteristic habitat substrate. The characteristics of the habitat types and their trophic and biogeochemical dynamics have been described in detail by Baird et al. $(2007,2011)$ based on data collected during the early to mid-1990s. The different subsystems are named according to either the dominant species such as mussel beds, Arenicola flats where the lugworm Arenicola marina predominates, the dwarf seagrass Zostera noltii as the dominant macrophytic species in the seagrass beds, or by typical substrate types (e.g. mud flats, muddy-sand flats, sandy shoals, and sandy beaches). The area each covers has changed over time due to the rapid increase of oysters on the mussel beds and the expansion of seagrass beds (see Table 1). The intertidal region is semi-diurnally inundated by tidal waters which import suspended material, such as organic particulates and phytoplankton, and dissolved material, with the flood tide, while ebb tides remove dissolved substances and resuspended particulate material (De Jonge \& van Beusekom 1995). Energy and material is exchanged between the overlying waters and the intertidal communities (e.g. suspension feeders). Changes in species biomass in the different subsystems and of the bight as a whole were obtained from published information, monitoring reports, and unpublished data deposited at the Alfred Wegener Institute for Polar and Marine Research (AWI). The standing stocks of the living and non-living compartments (and compartment number) of each model representing the 3 time periods are given (see Table 2).

\section{Model construction}

Three network models of the whole of the intertidal bight were constructed for 3 different time periods. The first one (SRB1) consists of 59 compartments, depicting the standing stocks of 56 living and 3 nonliving compartments, and the flows between them. The data contained in this model have been assembled during the years 1994 and 1995 and analyzed by means of ENA (cf. Baird et al. 2004a). This network was not changed from its original structure and format, with the exception of an adjustment of the zooplankton compartment to incorporate more realistic biomass data obtained from Martens (2007a) for that period, which resulted in minor changes in system attributes in the SRB1. In subsequent papers, Baird et al. $(2007,2011)$ discussed the trophic and biogeochemical dynamics of the 8 subsystems of the intertidal bight they identified. Reference to these subsystems is made because changes in the biodiversity, biomass of the different compartments, and areal extent have occurred in virtually all of them and thus had an impact on the bight as a whole. During subsequent years the mussel beds were invaded by the Pacific oyster Crassostrea gigas and the Australasian balanoid Austrominius modestus, while the abundance, biomass, and spatial extent of several other compartments of the ecosystem changed. Oyster biomass reached a peak in 2007 (Büttger et al. 2010), and a second model (SRB2) based on 2007 data was constructed to include 2 invasive species (C. gigas and A. modestus), and 2 native balanoid species (Semibalanus balanoides and Balanus crenatus), the biomasses of which have increased significantly since the early 1990s (Witte et al. 2010). Changes in other compartments of the food web were also incorporated such as the decline in blue mussel Mytilus edulis biomass (Büttger at al. 2010) and the dramatic increase in seagrass area (Reise \& Kohlus 2008) and its standing stocks in the bight. SRB2 thus consisted of 63 compartments, while the model topology was maintained for comparison with SRB1. Oyster and $A$. modestus biomass declined dramatically from 2007 to 2010, and a third model (SRB3) was subsequently constructed to assess possible changes in ecosystem function at reduced oyster and $A$. modestus abundance, also consisting of 63 compartments representing the status of the system during 2010. None of the standing stocks, the diet of the various heterotrophs, or the rates of flow between the compartments in the bight were derived from modeling estimates, but are based entirely on empirical data and results presented in the numerous publications and data sources 
cited in the text. Details of the construction of the SRB1 model are given in Baird et al. (2004a), and the same energetic ratios (such as the $C / B$ [consumption/biomass], $P / B$ [production/biomass], and $R / B$ [respiration/biomass] ratios) as in Baird et al. (2004a, $2007,2008,2011$ ) were used in the construction of the 2 subsequent models (SRB2 \& 3).

Each living compartment identified in each of the 3 networks was balanced in terms of energy uptake and dissipation (or respiration), growth, and egestion (in the case of heterotrophs). Energy budgets were determined for each of the 3 auto- and 56 (SRB1) and 60 (SRB2 \& 3) heterotrophic compartments identified in the bight ecosystem. For primary producers (phytoplankton, microphytobenthos, and macrophytes; mainly Fucus vesisiculosus in SRB1 and Zostera noltii in SRB2 \& 3) gross primary productivity (GPP) was assumed equal to the sum of net primary production (NPP), and respiration, and the values of GPP were considered as inputs into the system. This information is given in Baird et al. (2004a) for SRB1, while new biomass, production, and respiration values of the autotrophic compartments for 2007 and 2010 were, respectively, obtained from unpublished information generated by the AWI. The generalized energy budget was applied to all the heterotrophic compartments listed in Table 2, where energy uptake (or consumption, $C$ ) equals respiration $(R)+$ excretion $(E)+$ secondary production $(P)$. Rates of consumption, respiration, and production were based on the data given in Baird et al. (2004a, 2007). Zooplankton biomass for the flow models was obtained from Martens (2007a, 2010a, 2011), and biomass values for the common goby from M. Pockberger (pers. comm. AWI). The determination and literature sources of the energetics of most of the plant and animal species and communities occurring in the bight are given in detail by Baird et al. (2004a, 2007).

During the intervening years (1995 to 2010) regular monitoring and sampling of most of the compartments contained in the 1995 model (SRB1) were conducted by staff and students associated with the coastal ecosystems programme of the AWI Wattenmeer Station in List, Sylt, and through the Trilateral Monitoring and Assessment Program (TMAP). Changes in the standing stocks and energy budget parameters over the years were incorporated, respectively, in the SRB2 and SRB3 models for the reasons mentioned above. These changes are reflected in the biomass of the various compartments presented in Table 2. Two of the most striking changes since 1995 were the dramatic increase in oyster number and biomass and in the areal extent and standing stocks of seagrass plants. Oyster abundance on the mussel beds is regularly monitored (cf. Büttger et al. 2010), and numbers were converted to carbon standing stock in the entire bight by multiplying the carbon biomass per square meter by the mussel/oyster bed area (1.29 and $1.35 \mathrm{~km}^{2}$ in 2007 and 2010, respectively), divided by the total intertidal area of $135 \mathrm{~km}^{2}$. Oysters are non-specific filter feeders, feeding mainly on phytoplankton and suspended particulate organic carbon (POC) particles. Oyster energetics were derived from the ratios given by Baird \& Ulanowicz (1989) and McLusky (1989). The trend in oyster biomass from 2003 to 2010 is illustrated in Fig. 2.

As species and communities do not occur in all of the subsystems identified in the bight, nor at the same levels of abundance if they do occur in $>1$ subsystem (Baird et al. 2007), the biomass of each compartment in the intertidal bight was weighted according to the area in which it occurred. Furthermore, the areal extent of each habitat has not remained constant over the past $15 \mathrm{yr}$. For example, although the abundance of mussels on mussel beds declined since 1995 (Büttger et al. 2010), the size of the mussel beds increased from $0.36 \mathrm{~km}^{2}$ in 1995 to $1.29 \mathrm{~km}^{2}$ in 2007 to $1.35 \mathrm{~km}^{2}$ in 2010 because of oyster settlement, expansion, and growth on the mussel bed substrate. The recovery of seagrasses in the intertidal bight (Reise \& Kohlus 2008) has resulted in an expansion since 1995 of the area covered.

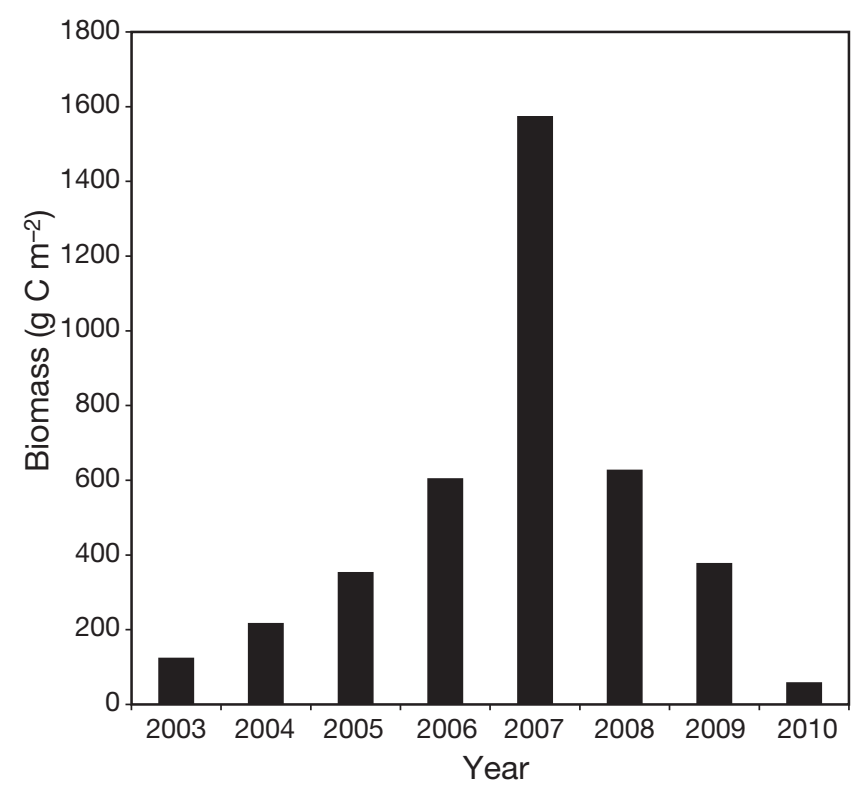

Fig. 2. Crassostrea gigas. Trend in the biomass of the Pacific oyster in the intertidal region of the Sylt-Rømø Bight for the period 2003 to 2010 (data extracted from Büttger et al. 2010) 
Each of the models was assumed to represent a steady-state condition in the sense that the inputs (GPP or $C$ ) in each of the living compartments of the networks were balanced by corresponding outputs (i.e. $R$ and NPP for autotrophs and $E+R+P$ for heterothrophs). This assumption implies that the ecosystem as a whole also occurs in a steady-state and assumes the underlying principle of the conservation of mass, namely that total inputs are balanced by total outputs. The mass-balancing of trophic networks, however, has limitations and weaknesses (Menge 1995, Baird et al. 2004b), while Baird et al. (2009) commented on the consequences of the balancing of networks on the properties derived from ENA. Here we present results from network analysis based on the steady states of 3 models. Phytoplankton production in intertidal waters $\left(247,220\right.$, and $323 \mathrm{mgC} \mathrm{m}^{-2}$ $\mathrm{d}^{-1}$ in 1995, 2007, and 2010, respectively) was insufficient to satisfy consumer demand, and the shortfall was imported from the adjacent coastal North Sea (Asmus \& Asmus 2011), where the mean production is on the order of $1178 \mathrm{mgC} \mathrm{m}^{-2} \mathrm{~d}^{-1}$ (Rick et al. 2006). Excess production and egestion by water-column free-living bacteria, and zooplankton excretion, were assumed to remain in suspension as POC, while short falls in suspended POC were also imported from the adjacent Wadden Sea where its concentration is higher than over the intertidal area. Excretory products of benthic invertebrates, fish, and birds, and all unutilised production of the benthos, were assumed to become sediment detritus (sediment POC) which was considered as the energy source for benthic bacteria, while excess sediment detritus was considered an export from the system where water movements are known to remove excess material (Asmus \& Asmus 1998). Where predator demand exceeds prey production we assumed that predators will feed off the remaining biomass, or switch to other prey, and we thus did not 'import' additional prey biomass in order to balance those specific living compartments, namely Nos. 9, 13, 14, and 19 (Table 2), the production of which was lower than predator demand. Bird production and excess fish production were exported from the system. An aggregate layout of the flow models is shown in Fig. 3.

\section{Ecological network analysis}

Input data for network analysis require information on the standing stock of each compartment and the flows between them within the ecosystem, as well as imports to and exports from the system. These input data files are available in an online supplement at www.int-res.com/articles/suppl/m462p143_supp/. The data are cast in the conventional SCOR format, and the routine (NETWRK4.2a) that performs the analysis of the input data and supporting documentation can be downloaded from www.cbl.umces.edu/ ulan/ntwk/netwrk.html.

The output from network analysis provides many useful indices and system properties of natural ecosystems, and relevant information on the interpretation of energy and nutrient flows, how these affect the structure of the ecosystem, and how one may wish to direct management or monitoring actions for the conservation or rehabilitation of biodiversity and ecosystem function (Christian \& Thomas 2003). Output from network analysis was used to assess changes over time of the Sylt-Rømø Bight and on the trophic dynamics of the ecosystem.

Input-output analysis measures the importance of the direct or indirect effect of any particular transformation or flow on any other compartment (or species) (Hannon 1973, Szyrmer \& Ulanowicz 1987). This analysis includes a routine called IMPACTS that quantifies the relative direct or indirect impact (or effect) that any one compartment can have on any other in the flow network (Ulanowicz \& Puccia 1990). We applied the IMPACTS routine to the SRB2 model to assess the impact of oysters when it was at its highest abundance in the intertidal bight, and thus provided a snapshot of trophic effects the oyster may have had on any of the other compartments in the food web.

The Lindeman trophic aggregation routine transforms each complex network of trophic transfers into a linear food chain with discrete trophic levels (i.e. the Lindeman Spine). The Lindeman Spine illustrates the amount of material or energy that each level receives from the preceding one, as well as the fraction lost from each level through respiration and export, and the net production passed on to the next higher level. It also shows the pool of recycled detrital material, which, together with the inputs to the autotrophs, forms the first trophic level. The Lindeman Spine allows the calculation of the efficiency of trophic transfer for each level, as well as at the whole-system level, which can be derived from the logarithmic mean of the efficiencies of each integer trophic level (Baird \& Ulanowicz 1989). We used the trophic level analysis to create Lindeman Spines for each time period to assess changes in flow efficiency over time.

The biogeochemical cycle routine of NETWRK assesses the structure and magnitude of the cycling of material in the system (Finn 1976). The cycle distribution gives the amount of material that flows 


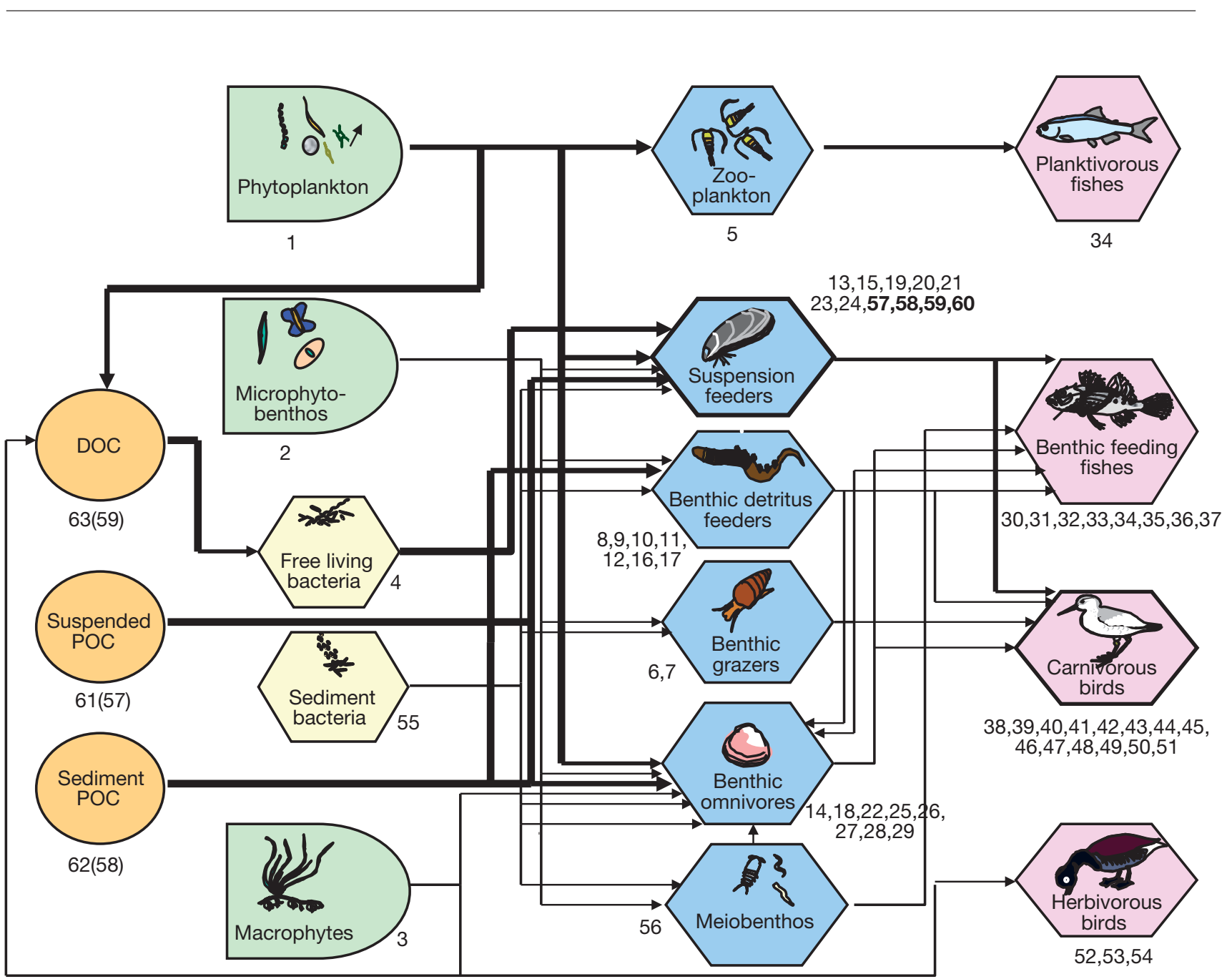

Fig. 3. An aggregated layout of the food web of the Sylt-Rømø Bight ecosystem. The 63 compartment models are aggregated into various biotic trophic guilds. The numbers at each guild refer to the different species or communities listed in Table 2. Numbers in brackets for the dissolved organic carbon (DOC), suspended particulate organic carbon (POC), and sediment POC pools refer to the compartment numbers of the 1995 model (Baird et al. 2004a). Numbers in bold refer to the 4 new compartments added to the suspension feeder guild and are 57 (oysters), 58 (Semibalanus), 59 (Balanus), and 60 (Austrominius) (adapted from Baird et al. 2004a). Thick black lines indicate major energy flow pathways. Orange circles indicate non-living compartments, green bullet shaped ones primary producers, yellow hexagons the bacterial compartments, blue ones the invertebrate benthic compartments, and pink ones vertebrate communities (adapted from Baird et al. 2004a)

through cycles of various lengths, where a cycle represents a series of transfers between compartments beginning and ending in the same compartment without going through the same compartment twice (Baird et al. 2004a). The Finn cycling index (or FCI) is derived from the fraction of the sum of flows that is devoted to cycling, and is equal to Tc/TST, where Tc is the amount recycled and TST (total systems throughput) is the sum of all flows in the ecosystem. The FCI is an index of the retentiveness of the system (Baird \& Ulanowicz 1989, Baird et al. 2004b).

The average path length (APL) is a system descriptor that measures the average number of compartments that a unit of $\mathrm{C}$ (or energy, or material) passes through from its entry into the system until it leaves.
The APL is defined by (TST $-Z) / Z$, where $Z$ equals the sum of all exogenous inputs (Kay et al. 1989). The average residence time (ART) of material or energy in the system is the ratio between the total system biomass and the sum of all outputs (respiration and exports) for C (Christensen 1995).

Various global system indices, based on information theory, describe the developmental and organizational state of the ecosystem (Ulanowicz 1986, 2004). The TST measures the extent of the total activity of the system, and is calculated as the sum of all the flows through all compartments, and relates to the size of the system. The system ascendency $(A)$, which is a single measure of the magnitude and diversity of flows between compartments, reflects on 
the functional attributes of the system. It incorporates both the size and organization of flows into a single index, and is formally expressed as the product of TST and the average mutual information (AMI) inherent in the flow network. Complex trophic structure and high system productivity enhance $A$. AMI, an information theoretic index (A/TST, or normalized ascendency), is a useful index of the organization inherent in a system and indicative of the developmental status of the ecosystem and thus of its inherent organization, i.e. the degree of specialization of flows in the network (Ulanowicz 2004). A high AMI value is found when the food web has the features of a food chain where the flow is unidirectional and predictable, whereas a low AMI value indicates that all, or most, of the compartments are connected to each other and a unit of energy leaving one has the probability to be consumed by others with equal probability (Miehls et al. 2009). The development capacity (DC) is the product of TST and the flow diversity. It measures the potential for a system to develop and is the natural upper limit of $A$. The total system overheads (i.e. overheads on imports, exports, and dissipation) and redundancy $(R$, i.e. a measure of the uncertainty associated with the presence of multiple or parallel pathways among the compartments of the network (Kay et al. 1989, Ulanowicz \& Norden 1990) are numerically represented by the difference DC $A$, and represent that fraction of the DC that does not appear to be organized structure (Bodini \& Bondavalli 2002). The magnitudes of the imports and exports reflect on the self-reliance of a system, i.e. the higher these values, the more dependent the system becomes on external exchanges. A system with low redundancy is considered to be susceptible to external perturbations, which may impact the trophic interactions between system compartments. Parallel pathways of energy and material transfers on the other hand, can act as a buffer or reserve should external perturbations or changes in biodiversity occur. It is postulated that a sustainable system requires a balance between $A$ and $R$, for should a perturbation occur, the system can draw from the overhead to keep it in operation (Ulanowicz 1986, Baird et al. 1991, Scharler \& Baird 2005). Internal ascendency $\left(A_{j}\right)$ and internal developmental capacity $\left(D_{\mathrm{i}}\right)$ are functions of internal exchanges alone, and thus exclude exogenous transfers. The ratios $A / D C$ and $A_{\mathrm{i}} / \mathrm{DC}$ have been used to compare the organizational status of ecosystems on temporal (Baird \& Ulanowicz 1989, Baird \& Heymans 1996, Baird et al. 1998, 2004b, Miehls et al. 2009) and spatial (Baird et al. 1991, Baird \& Ulanowicz 1993, Baird 1998, 1999, Baird et al. 2007) scales. The magnitudes of various attributes, particularly the $\mathrm{DC}, A$, overheads, and $R$, are strongly influenced by the TST (cf. Ulanowicz 2004). By dividing theses capacities (DC, A, and overheads) by TST, the resultant normalized values are scaled to eliminate the singular effect of TST (cf. Baird \& Ulanowicz 1989, Baird et al. 1998). DC, A, and $R$ are expressed as 'bits' which refers to the $\log _{2}$ used in the algorithms to calculate these quantities.

Flow diversity, defined as DC/TST (or normalized DC), measures both the number of interactions and the evenness of flows in the food web, and is thus a much more dynamic concept than species diversity (Mann et al. 1989, Baird et al. 1998). Comparatively higher values of this index indicate an increase in

Table 1. General system attributes of the intertidal Sylt-Rømø Bight (SRB) for 3 time periods 1995, 2007, and 2010. P/B: production/biomass; NPP: net primary production

\begin{tabular}{|c|c|c|c|}
\hline Attribute & 1995 (SRB1) & 2007 (SRB2) & 2010 (SRB3) \\
\hline Intertidal area (ha) & 135 & 135 & 135 \\
\hline Approximate area covered by sea grass beds (Zostera noltii) $\left(\mathrm{km}^{2}\right)$ & 15.53 & 57.92 & 82.93 \\
\hline Approximate area of mussel/oyster beds $\left(\mathrm{km}^{2}\right)$ & 0.36 & 1.29 & 1.35 \\
\hline Biomass of seagrass beds including Fucus $\left(\mathrm{mg} \mathrm{C} \mathrm{m}^{-2}\right)$ & 2960 & 11484 & 17282 \\
\hline Biomass of all primary producers $\left(\mathrm{mg} \mathrm{C} \mathrm{m}^{-2}\right)$ & 4136 & 16821 & 18506 \\
\hline Total system biomass of living compartments $\left(\mathrm{mg} \mathrm{C} \mathrm{m}^{-2}\right)$ & 35110 & 61369 & 52422 \\
\hline Biomass of invasive $\operatorname{species}^{\mathrm{a}}\left(\mathrm{mg} \mathrm{C} \mathrm{m}{ }^{-2}\right)$ & 0 & 16343 & 675 \\
\hline Invasive species biomass as proportion of total system biomass (\%) & 0 & 26.7 & 1.3 \\
\hline Production rate of invasive species $\left(\mathrm{mg} \mathrm{C} \mathrm{m}^{-2} \mathrm{~d}^{-1}\right)$ & 0 & 18.9 & 0.96 \\
\hline Seagrass biomass as proportion of total system biomass (\%) & 8.4 & 18.7 & 33.0 \\
\hline Biomass of system without seagrass beds and invasive species $\left(\mathrm{mg} \mathrm{C} \mathrm{m}^{-2}\right)$ & 32156 & 33542 & 34466 \\
\hline System $P / B$ ratio $\left(\mathrm{d}^{-1}\right)$ & 0.036 & 0.022 & 0.030 \\
\hline NPP efficiency (\%) & 57.0 & 98.0 & 59.0 \\
\hline Detrivory/Herbivory ratio & $1.25: 1$ & $0.97: 1$ & $1.27: 1$ \\
\hline${ }^{\mathrm{a}}$ Crassostrea gigas and Astrominius modestus & & & \\
\hline
\end{tabular}


interactions and a lower degree of unevenness and variability in the flow structure (Baird et al. 2004b). The effective number of connections between compartments is given by 3 connectance indices, and is derived from the log-averaged number of links calculated from the systems overhead. The overall connectance includes the effect of external transfers; the internal connectance index characterizes only internal exchanges, whereas the food web connectance index refers only to transfers among the living compartments in the system (Ulanowicz 2004).

\section{RESULTS}

\section{General system characteristics}

The general system attributes of the intertidal bight are given in Table 1. Clearly a number of structural changes have occurred over the period 1995 to 2007 to 2010. There has been a noticeable increase in the biomass of the living compartments in the intertidal region of the bight since 1995. The system's total biomass increased from an average of $35 \mathrm{gC} \mathrm{m}^{-2}$ in 1995 to $61 \mathrm{gC} \mathrm{m}^{-2}$ in 2007, after which it declined by about $15 \%$ to $52 \mathrm{gC} \mathrm{m}^{-2}$ in 2010. The increase in biomass was the result of a significant increase in the areal distribution of seagrass beds of Zostera noltii (Reise \& Kohlus 2008). Seagrass beds increased in size in the North Frisian Wadden by $273 \%$ between 1995 and 2007, and by a further $43 \%$ from 2007 to 2010 ; thus, a $>4$-fold increase in area occurred between 1995 and 2010, as derived from aerial surveys and ground truth measurements at selected sites (Table 1). Reise $\&$ Kohlus (2008) are of the opinion that the main cause for the increase in seagrass area in the northern Wadden Sea is due to a decrease in the frequency and magnitude of episodic storm surges which resulted in a decrease in sediment mobility and that
Table 2. Annual averaged biomass of the compartments in the Sylt-Rømø Bight for the 3 time models. Biomass values given in $\mathrm{mgC} \mathrm{m}^{-2}$

\begin{tabular}{|c|c|c|c|c|}
\hline $\begin{array}{l}\text { Comp. } \\
\text { no. }\end{array}$ & $\begin{array}{l}\text { Compartment } \\
\text { name }\end{array}$ & $\begin{array}{l}1995 \\
\text { SRB1 }\end{array}$ & $\begin{array}{l}2007 \\
\text { SRB2 }\end{array}$ & $\begin{array}{l}2010 \\
\text { SRB3 }\end{array}$ \\
\hline \multicolumn{5}{|c|}{ Living compartments } \\
\hline 1 & Phytoplankton & 1040.0 & 722.0 & 1093 \\
\hline 2 & Microphytobenthos & 136.2 & 133 & 131.1 \\
\hline 3 & Macrophytes & 2960.0 & 11484.0 & 17282 \\
\hline 4 & Free-living bacteria & 9.8 & 9.8 & 9.8 \\
\hline 5 & Zooplankton & 164.6 & 137.12 & 125.7 \\
\hline 6 & Hydrobia ulva & 1888.0 & 5119.2 & 6692 \\
\hline 7 & Littorina littorea & 67.9 & 430.6 & 474.1 \\
\hline 8 & Arenicola marina & 5913.0 & 7823.5 & 8855.5 \\
\hline 9 & Scoloplos amiger & 1030.2 & 617.4 & 471.1 \\
\hline 10 & Capitellidae & 25.7 & 84.7 & 99.2 \\
\hline 11 & Oligochaeta & 84.0 & 157.7 & 165.8 \\
\hline 12 & Heteromastus & 72.0 & 110.0 & 77.8 \\
\hline 13 & Lanice conchilega & 63.5 & 37.6 & 27.8 \\
\hline 14 & Nereis diversicolor & 193.5 & 193.5 & 101.4 \\
\hline 15 & Pygospio elegans & 127.7 & 108.5 & 98.7 \\
\hline 16 & Corophium arenarium & 52.1 & 52.1 & 52.1 \\
\hline 17 & Corophium volutator & 257.2 & 257.2 & 129.2 \\
\hline 18 & Gammarus spp. & 2.24 & 20.1 & 8.4 \\
\hline 19 & Mytilus edulis & 2030.0 & 610.0 & 170.3 \\
\hline 20 & Cerastoderma & 11400 & 8642.4 & 8046.4 \\
\hline 21 & Mya arenaria & 2076.8 & 2059.3 & 1399.8 \\
\hline 22 & Small polychaetes & 199.0 & 209.6 & 207.6 \\
\hline 23 & Tharyx killariensis & 24.0 & 72.8 & 101.7 \\
\hline 24 & Macoma baltica & 2652.0 & 2642.7 & 2540.3 \\
\hline 25 & Phyllodocidae & 10.0 & 38.3 & 55.3 \\
\hline 26 & Small crustaceans & 333.0 & 385.3 & 284.9 \\
\hline 27 & Carcinus maenas & 34.5 & 110.2 & 130.1 \\
\hline 28 & Crangon crangon & 31.0 & 30.8 & 29.2 \\
\hline 29 & Nephthys hombergii & 484.3 & 398.7 & 391.1 \\
\hline 30 & Pomatoschistus microps (common goby & 3.2 & 6.6 & 8.9 \\
\hline 31 & P. minutus (common goby) & 0.47 & 0.47 & 0.47 \\
\hline 32 & Plaice (Pleuronectes platessa) & 0.03 & 0.03 & 0.038 \\
\hline 33 & Flounder (P. flesus) & 0.004 & 0.011 & 0.014 \\
\hline 34 & Herrings & 0.0073 & 0.0073 & 0.0073 \\
\hline 35 & Whiting (Merlangius merlangus) & 0.53 & 0.53 & 0.53 \\
\hline 36 & Cod (Gadus morhua) & 0.02 & 0.025 & 0.02 \\
\hline 37 & Bull rout (Myoxocephalus scorpius) & 0.020 & 0.072 & 0.075 \\
\hline 38 & Shelduck & 18.6 & 18.6 & 9.3 \\
\hline 39 & Eider & 48 & 98.6 & 98.2 \\
\hline 40 & Oystercatcher & 10.9 & 22.4 & 22.3 \\
\hline 41 & Avocet & 0.9 & 0.9 & 0.45 \\
\hline 42 & Golden plover & 3.2 & 3.2 & 3.2 \\
\hline 43 & Knot & 2.7 & 2.7 & 2.7 \\
\hline 44 & Dunlin & 4.6 & 4.6 & 4.6 \\
\hline 45 & Bar-tailed godwit & 2.7 & 1.4 & 0.93 \\
\hline 46 & Curlew & 4.9 & 4.9 & 4.86 \\
\hline 47 & Black-headed gull & 2.1 & 1.4 & 2.1 \\
\hline 48 & Common gull & 2.2 & 2.2 & 2.2 \\
\hline 49 & Herring gull & 7.7 & 27.6 & 28.9 \\
\hline 50 & Other birds & 6.2 & 6.2 & 6.2 \\
\hline 51 & Mallard & 8.8 & 8.8 & 4.4 \\
\hline 52 & Pintail & 2.6 & 2.6 & 1.3 \\
\hline 53 & Widgeon & 38.0 & 141.7 & 202.9 \\
\hline 54 & Brent goose & 10.0 & 37.3 & 53.4 \\
\hline 55 & Sediment bacteria & 625.0 & 625 & 625 \\
\hline 56 & Meiobenthos & 944.5 & 832.2 & 749.6 \\
\hline 57 & Crassostrea gigas (oyster) & 0 & 15050.0 & 550.0 \\
\hline 58 & Semibalanus & 0 & 427.5 & 640.0 \\
\hline 59 & Balanus & 0 & 50.3 & 24.0 \\
\hline \multirow[t]{2}{*}{60} & Austrominius & 0 & 1293.2 & 124.7 \\
\hline & Total system biomass & 35110.1 & 61369.2 & 52422.7 \\
\hline \multicolumn{5}{|c|}{ Non-living compartments } \\
\hline 61 & Suspended POC (\#57 in SRB1) & 167.4 & 164.4 & 175.1 \\
\hline 62 & Sediment POC (\#58 in SRB1) & 19000 & 13106 & 17971 \\
\hline 63 & DOC (\#59 in SRB1) & 62.1 & 62.1 & 109.2 \\
\hline
\end{tabular}


this increase in sediment stability enhanced seagrass expansion. By extrapolation of the data of the North Frisian Wadden Sea to the scale of the Sylt-Rømø Bight seagrass bed expansion occurred at the expense of areal loss of the Arenicola flats, mud flats, and muddy-sand flats, the collective area of which declined from about $108 \mathrm{~km}^{2}$ in 1995 to approximately $40 \mathrm{~km}^{2}$ in 2010, roughly equivalent to the area of seagrass expansion (Table 1). Under these assumptions, biomass of seagrass, mainly Zostera noltii, increased simultaneously by $288 \%$ between 1995 and 2007, and by about $50 \%$ from 2007 to 2010 (Table 2). Subsequently, the proportion of seagrass biomass to that of the entire intertidal area increased from $8 \%$ in 1995, to $19 \%$ in 2007 and to $33 \%$ in 2010 (Table 1). Secondly, a dramatic increase has taken place since 2002 in the abundance and biomass of 2 invasive species namely the Pacific oyster Crassostrea gigas (Büttger et al. 2010) and the balanoid Austrominius modestus (Witte et al. 2010), which was facilitated by a succession of anomalously mild winters and strong oyster spat falls during the years 2001 to 2009 (Nehls et al. 2006, Büttger et al. 2011). Oysters and A. modestus increased from very low numbers to a peak in 2007, when their respective biomasses were estimated at 15 and $1.3 \mathrm{gC} \mathrm{m}^{-2}$, respectively (Table 2 ). The biomass of both species declined during the following years and was estimated at about 0.55 and $0.12 \mathrm{gC} \mathrm{m}^{-2}$, respectively, in 2010 (Büttger et al. 2010, Witte et al. 2010), while their collective production rates declined from 19 to $1 \mathrm{mgC} \mathrm{m}^{-2} \mathrm{~d}^{-1}$ (Table 1 ). The biomass of these 2 invasive species constituted about $27 \%$ of the system's total biomass in 2007, but only $1.3 \%$ in 2010 (Table 1). The decline in the abundance of oysters since 2007 is ascribed to recruitment failure since 2008 compounded by high mortality because of a severely cold 2009/2010 winter, when oyster mortality was about $90 \%$ between the autumn of 2009 and the spring of 2010 in the Sylt-Rømø Bight (Büttger et al. 2011). Indeed, the decrease in bivalve larvae since 2007

Table 3. Abundance of bivalve larvae in the Sylt-Romo Bight 2005 to 2010 during summer (July to September), and the total abundance for each year (January to December).

\begin{tabular}{|lcrrl|}
\hline Year & $\begin{array}{c}\text { Summer } \\
\text { period }\end{array}$ & $\begin{array}{c}\text { No. } \mathrm{m}^{-3} \\
\text { summer }\end{array}$ & \multicolumn{1}{c|}{ No. $^{-3}$} & Source \\
$\mathrm{yr}^{-1}$ & \\
\hline 2005 & 4 Jul-29 Sep & 15087 & 187086 & Martens (2007b) \\
2006 & 3 Jul-28 Sep & 5259 & 138515 & Martens (2007c) \\
2007 & 2 Jul-27 Sep & 457 & 58732 & Martens (2010a) \\
2008 & 3 Jul-29 Sep & 915 & 4399 & Martens (2010b) \\
2009 & 2 Jul-30 Sep & 1370 & 5828 & Martens (2010c) \\
2010 & 1 Jul-29 Sep & 10685 & 32974 & Martens (2011) \\
\hline
\end{tabular}

(Table 3) gives a crude hint that low recruitment and spat fall could well have been the cause of oyster decline from 2007 to 2010 (Fig. 2). The biomass of the blue mussel Mytilus edulis on the mussel beds declined by about $60 \%$ between 1998 and 2010 (Büttger et al. 2010), which Nehls et al. (2006) ascribed to failed recruitment/spat fall due to mild winters and the resultant synchronized settling of mussel spat and their main predators such as crabs. The areal extent of the mussel-oyster beds nevertheless increased (Table 1) due to oyster settlement and growth (Büttger et al. 2010).

Apart from the increases of seagrass and the biomass of invasive species, the collective biomass of all the other living compartments increased only marginally over the years, namely by about $4 \%$ from 1995 to 2007 , and by approximately $3 \%$ from 2007 to 2010 (Table 1). Some of the species listed in Table 2 show variable fluctuations in biomass, some increased, while others decreased in abundance over the past 15 yr. The average daily $P / B$ ratios (or turnover ratio), given in Table 1, are considered to provide an index reflecting that the functional and trophic activities of ecosystems (Christensen 1995) declined from 1995 to 2007, when it was calculated at the lowest of the 3 periods, and during a time when the 2 invasive species were present in high abundance. When both of these decreased, the $P / B$ ratio increased again by about $36 \%$ from 2007 to 2010 ; this ratio was nevertheless higher in 1995 than in the other 2 time stanzas.

\section{Network analysis}

The carbon flow networks of the 3 models were cast into the simplified Lindeman Spines, illustrated in Fig. 4. In the top panel of each model (Fig. 4a, c, e) the detritus pool is separated from the primary producers and shows the relevant amounts of herbivory and detrivory, as well as the returns from each trophic level to the detritus pool and the contribution of plants to the detritus pool. These figures also illustrate that about 56,50 , and $56 \%$ of the total energy passing from the 1st to the 2nd trophic level (TL) consists of recycled material of the SRB1, SRB2, and SRB3 models, respectively, and that approximately 92,89 , and $94 \%$ of detritus inputs into the respective detrital pools of the 3 models are derived from recycling within the system. Returns from each trophic level and the imports into the detrital pool, GPP (an energy input into TL I), the canonical exports, and respiration leaving each trophic level are also shown in Fig. 4. When the detritus pool and the primary pro- 

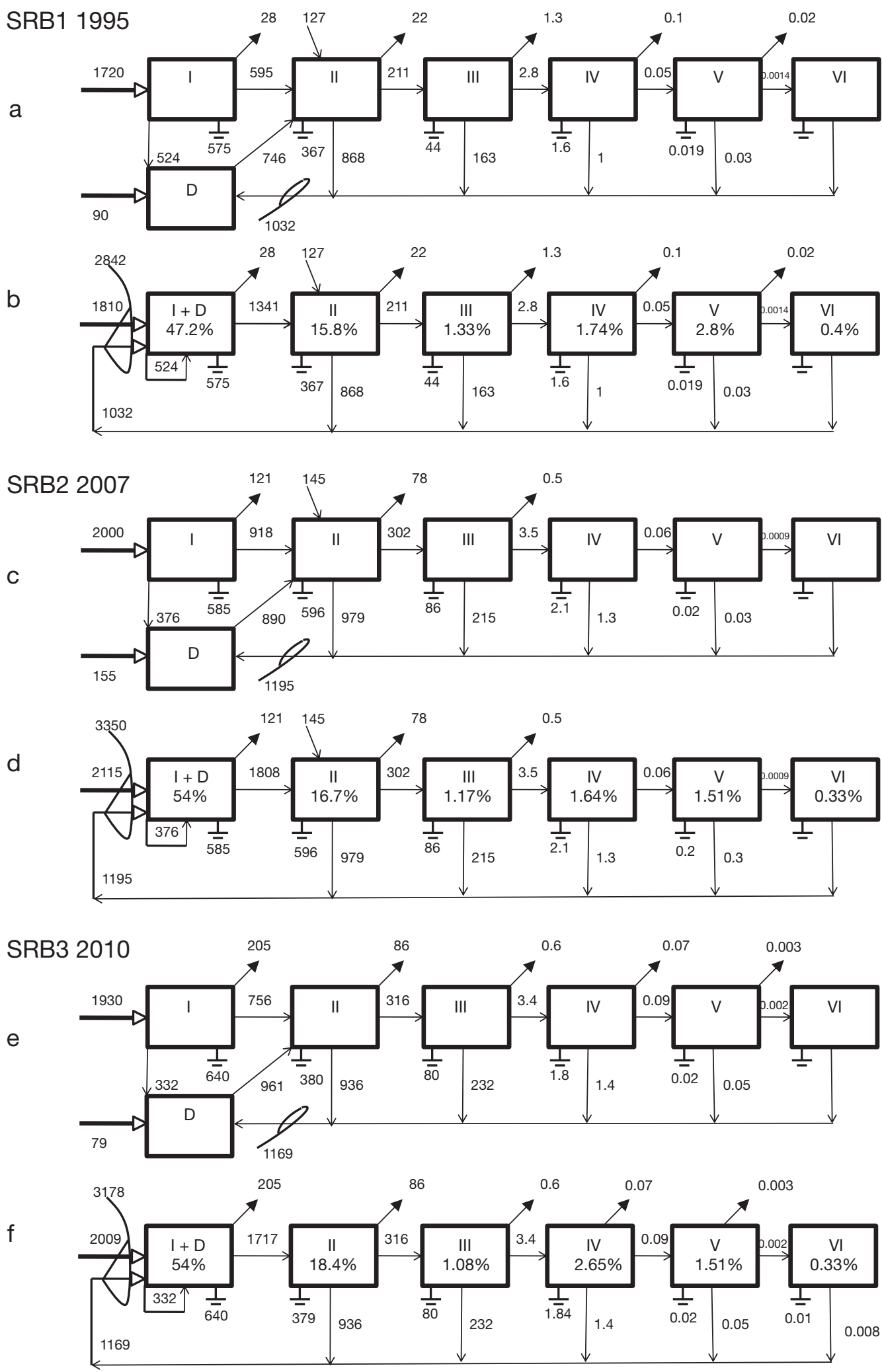

Fig. 4. The Lindeman Spines for each of the 3 models (a,b) SRB1 (1995), (c,d) SRB2 (2007), and (e,f) SRB3 (2010). In Panels a, c, and e the detritus pool (D) is separate from the primary producers at trophic level TL 1 (box I) where all the inputs into D are shown as well as the uptake of detritus at TL II. In Panels b, d, and f TL I and D are merged in the concatenated Lindeman Spines. The percent value in each of the TL boxes gives the amount of input into that level that is passed on to the next higher TL. Roman numerals in each box indicate the different trophic levels. Open arrows indicate inputs to TL I and D, filled arrows indicate exports from different trophic levels. Arrows between trophic levels (boxes) show amount of carbon passed from the lower to the next higher trophic level. Respiration at each trophic level is indicated by $\perp$. All inputs, exports, respirations, and flows are given in $\mathrm{mg} \mathrm{C} \mathrm{m}^{-2} \mathrm{~d}^{-1}$ 
ducers are combined in the first trophic level, the inputs and outputs from that level show the total amount of energy passed on to the second level in Fig. 4b,d,f. Roman numerals identify each trophic level, and the percentage of carbon received from the previous lower TL to the next higher TL is indicated in the trophic level boxes of each model. Eight trophic levels were identified in each model, although only miniscule amounts $(<0.0005 \%$ on average of the initial inputs at level I) were transferred from the fifth to higher TLs so that any effective measure of trophic transfer would hardly be affected by the higher levels. In all 3 models, the efficiency of transfer of the third level is lower than that of TL IV and V which can be ascribed to the relatively high returns of cycled material to the detrital pool from that level $(74 \%$ on average for the 3 models). The mean trophic efficiencies (i.e. the efficiency by which energy is transferred within the system) calculated over the first 5 trophic levels of the SRB1, SRB2, and SRB3 models are, respectively, 5.47, 4.82, and $5.91 \%$; a notable decline was seen in the 2007 model by about $12 \%$ compared the 1995 model, but was followed by an increase of nearly $23 \%$ in 2010 after the decrease in oyster and Austrominius modestus abundance (Table 4).

The APL and the ART are indices which also reflect on the trophic function of an ecosystem. The APL declined from 1995 to 2007 by $4 \%$, but then increased marginally in the 2010 model, implying that most of the energy was transferred over fewer steps during 2007 than during 1995 and 2010 (Table 4). The ART increased from 1995 to 2007 by about $40 \%$, but declined by $8 \%$ in the 2010 model; the ART in general increased over the years with material and energy remaining in the system for longer time periods (Table 4). The structure and magnitude of cycling has also changed since 1995 in the bight. The number of cycles decreased from 1197 in 1995 to 691 in 2007, but increased again to 737 from 2007 to 2010 . Despite a decrease in cycle number, the FCI nevertheless increased by $1.3 \%$ from 1995 to 2007 , by $28 \%$

Table 4. Global system indices and attributes derived from network analysis of the Sylt-Rømø Bight representing models (SRB1, SRB2, SRB3) over 3 different time periods. All abbreviations given in 'Ecological network analysis' in 'Materials and methods'

\begin{tabular}{|c|c|c|c|c|c|c|}
\hline System attributes & $\begin{array}{c}\text { SRB1 } \\
1995\end{array}$ & $\begin{array}{l}\text { SRB2 } \\
2007\end{array}$ & $\begin{array}{l}\text { Percent } \\
\text { change } \\
\text { SRB1 } \\
\text { to SRB2 }\end{array}$ & $\begin{array}{c}\text { SRB3 } \\
2010\end{array}$ & $\begin{array}{c}\text { Percent } \\
\text { change } \\
\text { SRB2 } \\
\text { to SRB3 }\end{array}$ & $\begin{array}{c}\text { Percent } \\
\text { change } \\
\text { SRB1 } \\
\text { to SRB3 }\end{array}$ \\
\hline Number of compartments & 59 & 63 & & 63 & & \\
\hline Trophic efficiency (logarithmic mean, \%) & 5.47 & 4.82 & -11.9 & 5.91 & 22.6 & 8.0 \\
\hline Number of cycles & 1197 & 691 & -42.3 & 737 & 6.7 & -38.4 \\
\hline Finn cycling index $(\%)$ & 16.61 & 16.83 & 1.3 & 21.59 & 28.3 & 30.0 \\
\hline Average path length $(\mathrm{APL}=\mathrm{TST}-Z / Z)$ & 2.69 & 2.58 & -4.1 & 2.61 & 1.2 & -3.0 \\
\hline Average residence time (ART; days) & 19.1 & 26.5 & 38.7 & 24.4 & -7.9 & 27.7 \\
\hline Total system throughput (TST; $\mathrm{g} \mathrm{C} \mathrm{m}^{-2} \mathrm{yr}^{-1}$ ) & 6993 & 8292 & 18.6 & 7874.0 & -5.0 & 12.6 \\
\hline Development capacity (DC; $\mathrm{g} \mathrm{C} \mathrm{m}^{-2} \mathrm{yr}^{-1}$ bits) & 34608 & 44012 & 27.2 & 41341 & -6.1 & 19.5 \\
\hline Ascendency $\left(A ; \mathrm{g} \mathrm{C} \mathrm{m}^{-2} \mathrm{yr}^{-1} \mathrm{bits}\right)$ & 13447 & 15960 & 18.7 & 14853 & -6.9 & 10.5 \\
\hline Relative ascendency (A/DC; \%) & 38.9 & 36.3 & -6.7 & 35.9 & -0.9 & -7.5 \\
\hline Average mutual information (A/TST, normalized $A$ ) & 1.92 & 1.92 & 0.00 & 1.89 & -2.0 & -1.9 \\
\hline Flow diversity (DC/TST, normalized DC) & 4.95 & 5.31 & 7.3 & 5.25 & -1.1 & 6.1 \\
\hline Overheads on imports ( $\mathrm{g} \mathrm{C} \mathrm{m}^{-2} \mathrm{yr}^{-1}$ bits) & 3529 & 5004 & 41.8 & 4665 & -6.8 & 32.2 \\
\hline Overheads on exports ( $\mathrm{g} \mathrm{C} \mathrm{m}^{-2} \mathrm{yr}^{-1} \mathrm{bits}$ ) & 1434 & 1920 & 33.9 & 2216 & 15.4 & 54.5 \\
\hline Dissipative overheads ( $\mathrm{g} \mathrm{C} \mathrm{m}^{-2} \mathrm{yr}^{-1}$ bits) & 4672 & 6519 & 39.5 & 6140 & -5.8 & 31.4 \\
\hline Redundancy $\left(R ; \mathrm{g} \mathrm{C} \mathrm{m}^{-2} \mathrm{yr}^{-1}\right.$ bits $)$ & 11527 & 14610 & 26.7 & 13467 & -7.8 & 16 \\
\hline Relative redundancy $(R / D C ; \%)$ & 33.3 & 33.2 & -0.3 & 32.6 & -1.9 & -2.2 \\
\hline Normalized redundancy $(R / \mathrm{TST})$ & 1.65 & 1.76 & 6.9 & 1.71 & -2.9 & 3.8 \\
\hline Internal development capacity ( $\left.\mathrm{DC}_{\mathrm{i}} ; \mathrm{g} \mathrm{C} \mathrm{m}^{-2} \mathrm{yr}^{-1} \mathrm{bits}\right)$ & 18427 & 22994 & 24.8 & 21469 & -6.6 & 16.5 \\
\hline 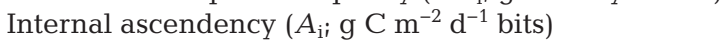 & 6900 & 8384 & 21.5 & 8002 & -4.6 & 16 \\
\hline Relative internal ascendency $\left(A_{\mathrm{i}} / \mathrm{DC}_{\mathrm{i}} ; \%\right)$ & 37.4 & 36.5 & -2.6 & 37.3 & 2.2 & -0.5 \\
\hline Average internal mutual information $\left(A_{\mathrm{i}} / \mathrm{TST}\right)$ & 0.99 & 1.01 & 2.5 & 1.02 & 0.5 & 3.0 \\
\hline Internal redundancy $\left(R_{\mathrm{i}} \mathrm{g} \mathrm{C} \mathrm{m}^{-2} \mathrm{yr}^{-1}\right.$ bits) & 11527 & 14610 & 26.7 & 13467 & -7.8 & 16.8 \\
\hline Normalized internal redundancy $\left(R_{\mathrm{i}} / \mathrm{TST}\right)$ & 1.6 & 1.8 & 6.9 & 1.7 & -2.9 & 3.8 \\
\hline$\Phi$ (sum of overheads/TST) & 1.38 & 1.62 & 17.7 & 1.65 & 2.0 & 20.0 \\
\hline Overall connectance & 2.285 & 2.411 & 5.5 & 2.426 & 0.6 & 6.2 \\
\hline Intercompartmental connectance & 2.843 & 3.159 & 11.1 & 3.030 & -4.1 & 6.6 \\
\hline Food web connectance (living compartments only) & 2.283 & 2.500 & 9.5 & 2.398 & -4.1 & 5.0 \\
\hline
\end{tabular}




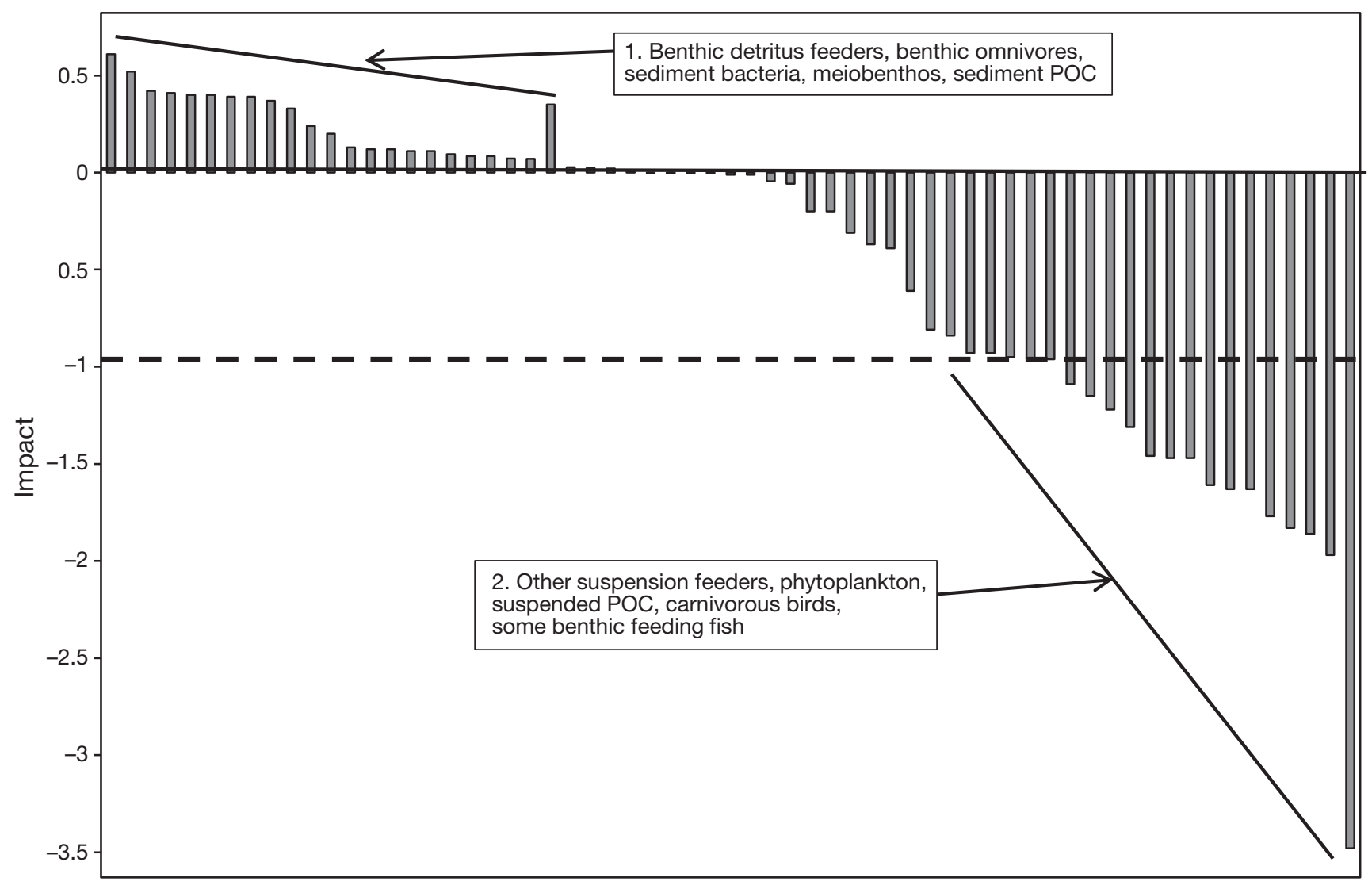

Model compartments (SRB2, 2007)

Fig. 5. Crassostrea gigas. Impact of the oyster on other compartments of the ecosystem. Dashed line below the zero line refers to those compartments most affected by the oyster. Box 1 and arrow indicate those compartments positively affected by the oyster. Box 2 and arrow indicate the compartments most impacted by the oyster

from 2007 to 2010 , and by $30 \%$ from 1995 to 2010 , indicating that the system has become more retentative over the years. The overhead on imports increased by about $40 \%$ from 1995 to 2007 , which can be ascribed to the greater consumption of phytoplankton, imported by tides, to satisfy the demand by suspension feeders such as the oyster.

IMPACTS analysis performed on the SRB2 model shows that the oyster has negative as well as positive effects on virtually all the system compartments. The oyster has positive impacts particularly on the benthic detritus feeders, benthic omnivores, sediment bacteria, and indirectly on zooplankton and some benthic feeding fish. Its negative impacts, which are quantitatively greater than the positive effects, are mainly on other suspension feeders that compete for the same energy sources such as phytoplankton and suspended POC (Fig. 5, also see Fig. 3). Positive effects of the oyster are again on those compartments which are dependent to some degree on sediment energy sources such as detritus, bacteria, and meio- benthos. The large amount of egesta by oysters most probably benefits those communities.

Results from ENA on the various metrics and ratios of each model are given in Table 4 . The coefficient of variance $(\mathrm{CV})$ has been calculated for each of the attributes calculated from ENA to provide a measure of parameter variability of the system indices calculated for each model. The calculated CVs of the system attributes are illustrated in Fig. 6, which clearly shows that the ratio-based indices have much lower $\mathrm{CV}$ values $(<5 \%)$, whereas those for the trophic structure and information metrics are much higher. The low variability of the ratio-based indices of all 3 models indicates that they are the most robust to parameter uncertainty and most useful for ecosystem assessment and comparative ecosystem analysis (Kaufman \& Borrett 2010, Baird et al. 2011). The high CVs for the information metrics in all 3 models illustrate the variability and differences in system activity, developmental, and organizational status of each. The actual values of the metrics such as TST, DC, $A$, 
and $R$, and trophic indices (trophic efficiency, FCI) are thus not directly comparable due to the high variability between them, whereas the low CVs of the ratios (relative ascendency, AMI, relative internal ascendency, relative internal redundancy, flow diversity, and food web connectance) are. Close scrutiny of the per cent change between SRB1 (1995) and SRB2 (2007) of the various indices, metrics, and ratios (third column with \% change values; Table 4) shows that most of them increased (positive sign) by various magnitudes. A few important system indices, however, declined (negative sign, bold). The trophic efficiency of the system decreased by $12 \%$, the APL by $4 \%$, the 2 relative ascendency ratios by 7 and $3 \%$, respectively, while the AMI remained constant. These data are considered to be good indices of the system's inherent organization, and their decline from 1995 to 2007 would indicate a less organized system in 2007. On the other hand, an increase in the flow diversity indicates an increase in interactions and a lower degree of unevenness and variability in the flow structure, while all the connectance indices also increased. The normalized redundancy ratios also increased by $7 \%$ so that the 'strength in reserve' increased marginally as the invasive species increased in abundance. A rather mixed bag of results, but nevertheless some indication that the bight ecosystem has changed and was by 2007 in a less organized state than during earlier years. The negative changes from 1995 (i.e. a decline in system properties), when invasive species were virtually absent from the bight, to 2007, when invasive species were highly abundant, are remarkably evident in only a few of the metrics and ratios. All observations, however, point to the impact of the invasive species as largely responsible for the decline in the few important indices mentioned above. On the other hand, virtually all metrics and attributes decreased after the dramatic decline in oyster and Austrominius modestus biomass from 2007 to 2010 (Table 4; percent change SRB2 to SRB3 column). Only the $P / B$ ratio (Table 1), the trophic efficiency index, the FCI, the APL, overhead on exports, the relative internal ascendency, and the internalized AMI increased. The relative and internal ascendencies, AMI, flow diversity, relative and normalized redundancies, and connectance indices, all declined from 2007 to 2010. The changes between 1995 and 2010 were all positive with the exception of the APL, the relative ascendancies, the AMI, and the relative redundancy (Table 4; percent change SRB1 to SRB3). Since calculations of the ecosystem indices discussed above are based on log-scaled measures (Ulanowicz 1986), small percentage changes reflect much larger disparities, and hence larger ecological changes (Baird \& Ulanowicz 1993).

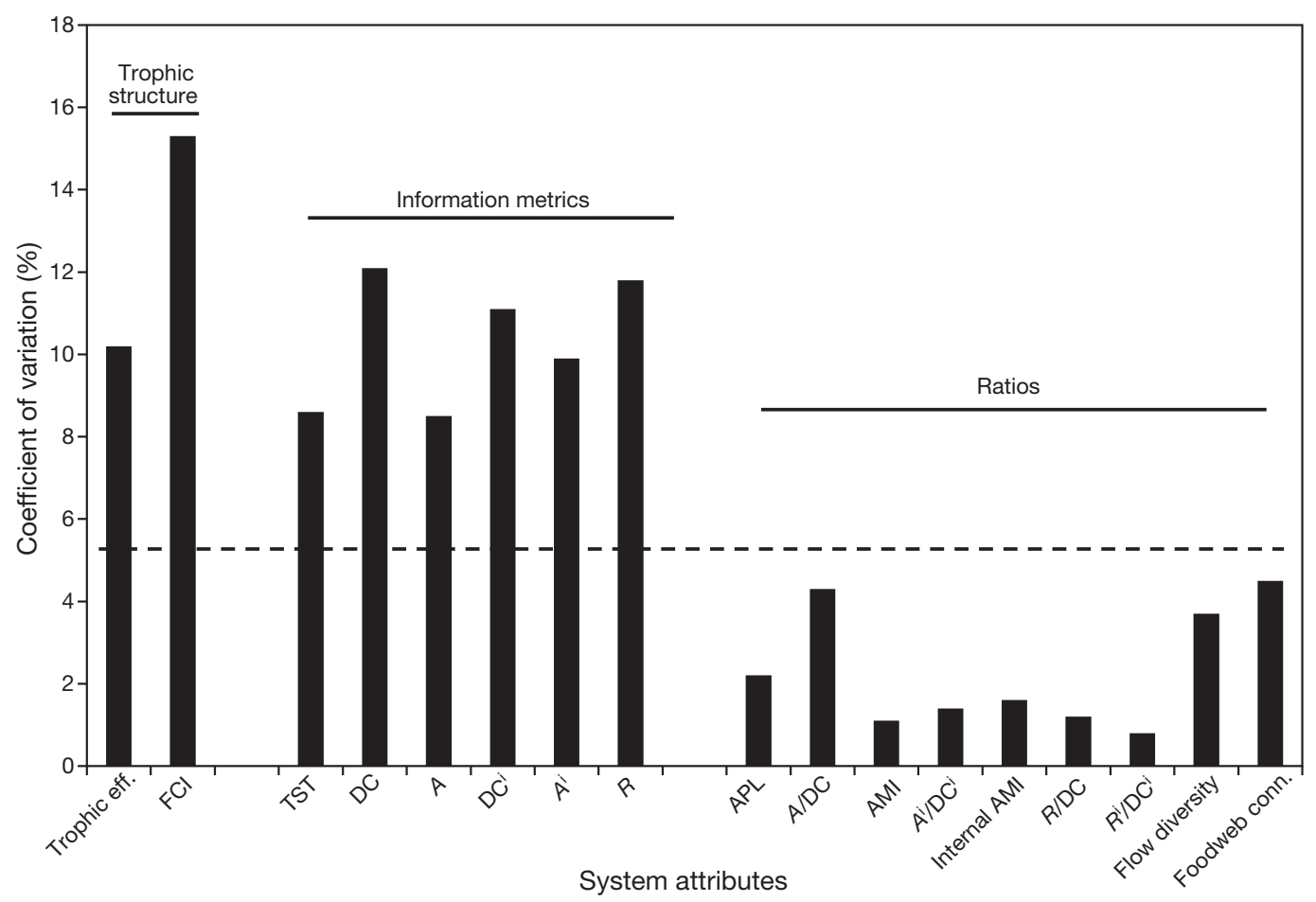

Fig. 6. Coefficients of variation of the various indices derived from network analysis. Dashed line: the $5 \% \mathrm{CV}$ value level; index abbreviations. For abbreviations see 'Materials and methods' 


\section{DISCUSSION}

Several studies have reported on the impact of invasive species on ecosystem function. In one of the few detailed analyses of the impact of invasive species on ecosystem structure and function, Miehls et al. (2009) concluded that the invasive zebra mussel Dreissena polymorpha has had a far reaching impact on the food web of Lake Oneida, New York, USA. Their results are based on the application of network analysis to the Lake Oneida food web which represents a prezebra mussel invasion (1986 to 1991) and a postinvasion period (1992 to 2002). The effects of zebra mussels included changes in the trophic flow efficiency, and alterations of the food web organization. Comparison of ENA results between Lake Oneida and the Sylt-Rømø Bight show that the 2 systems responded differently to invasive species. For example, the TST declined by $20 \%$ between the pre- and postinvasion of zebra mussel in Lake Oneida, whereas it increased by $19 \%$ in the bight from 1995 to 2007. Similarly, other metrics such as the A, DC, and $\varphi$ declined in Lake Oneida, but increased in the bight. However, some of the ratio-based indices show similar trends in the 2 systems. For example, the relative ascendency ratio $(A / D C)$ decreased by $3.4 \%$ in Lake Oneida, and by $6.7 \%$ in the bight, the AMI (A/TST) increased from pre- to post-invasion by $8 \%$, whereas no changes for this index were observed for AMI in the bight, while the flow diversity (DC/TST) increased by $2.6 \%$ in Lake Oneida and by $7.3 \%$ in the bight between the pre- and post-invasion time stanzas. A large difference exists in $\varphi$ (i.e. when the sum of the overheads is scaled by TST) between the 2 systems: it declined by $2.8 \%$ in Lake Oneida, whereas it increased by $17 \%$ in the bight, clearly illustrating a greater dependence on external connections in the bight than in Lake Oneida. Regime shifts were observed in phytoplankton, benthos, and fish shortly after the invasive mussels (Dreissena spp.) became established in the Bay of Quinte ecosystem (Lake Ontario) in 1993/1994 (Nichols et al. 2011). The trophic efficiency declined by 12 and $65 \%$ in the bight and Lake Oneida, respectively, between the pre- and post-invasive time stanzas; a substantial decline in the transfer of energy between the trophic levels particularly in Lake Oneida. Regime shifts were also observed in phytoplankton, benthos and fish shortly after the invasive mussels (Dreissena spp.) became established in the Bay of Quinte ecosystem (Lake Ontario) in 1993/1994 (Stewart \& Haynes 1994, Nichols et al. 2011).

Species other than suspension feeders have been reported to alter community structure and possibly ecosystem function. Zaiko et al. (2011) assessed the impact of invasive species (such as polychaetes) in the Baltic Sea ecosystem using the bioinvasion impact/ biopollution assessment system, and concluded that the impacts of alien species are not uniform, but they nevertheless recorded that several invasive species have yielded moderate to high 'biopollution' indices in the major part of the Baltic Sea. Rock lobsters Jasus lalandii expanded their distribution along the southwest coast of South Africa in the early 1990s causing the virtual elimination of the sea urchin Parechinus angulosus through predation (Blamey et al. 2010). The declines in herbivores (such as the sea urchin) by as much as $99 \%$ led to the increase in macroalgae and sessile invertebrates during the post-invasion period. Blamey et al. (2010) are of the opinion that the invasion by rock lobsters not only caused a regime shift in the ecosystem, but also had substantial economic consequences for the commercial exploitation of the abalone Haliotus midae, because its juveniles are intimately associated with the sea urchin. Invasions of alien species and their impact on ecosystem function are not restricted to animals. For example, Deudero et al. (2011) and Box et al. (2010) have reported on the impact on the community and food web structure of seagrass beds of Posidonia oceanica when colonized by an alien macroalga, Caulerpa racemosa, in the western Mediterranean.

The establishment and growth of invasive species, the Pacific oyster Crassostrea gigas in particular, have undoubtedly changed the structure of existing mussel beds in the Sylt-Rømø Bight where oysters have formed dense layers and solid surfaces, turning former mussel beds into oyster reefs (Nehls et al. 2006). This species has also impacted the functioning of mussel beds as an identifiable subsystem in the bight (Baird et al. 2007, Baird 2011). Here we assessed the impact by means of system properties derived from ENA of the invasive species on the whole bight ecosystem. The Lindeman trophic analysis indicates that some of the relationships between the trophic levels between the 3 models have changed. The efficiency for TL I increased by $7 \%$ and at TL II by about 1\% from 1995 (pre-invasion) to 2007 (high invasive biomass). The increase in efficiency at TL I is most probably due to a decrease in phytoplankton biomass (Table 2) and productivity and with more going into the grazing food chain while less is lost to the detritus pool, a phenomenon also observed by Miehls et al. (2009) in Lake Oneida. These dynamics are illustrated in Fig. 4a,c, which shows that grazing increased by $54 \%$ (595 to $918 \mathrm{mgC} \mathrm{m}^{-2} \mathrm{~d}^{-1}$ ) and the loss (from TL I to the detritus pool) decreased by 
about $28 \%$ (524 to $376 \mathrm{mgC} \mathrm{m}^{-2} \mathrm{~d}^{-1}$ ) in the 2007 model (i.e. the difference between 1995 and 2007). Consumption of phytoplankton increased from $410 \mathrm{mgC} \mathrm{m}^{-2} \mathrm{~d}^{-1}$ in 1995 to $589 \mathrm{gC} \mathrm{m}^{-2} \mathrm{~d}^{-1}$ in 2007 , while oysters and Austrominius modestus alone consumed $208 \mathrm{mgC} \mathrm{m}^{-2} \mathrm{~d}^{-1}$ (or about $35 \%$ of the total phytoplankton uptake). These values declined to $360 \mathrm{mgC} \mathrm{m}^{-2} \mathrm{~d}^{-1}$ (total phytoplankton uptake) and $8 \mathrm{mgC} \mathrm{m}{ }^{-2} \mathrm{~d}^{-1}$ (invasive species uptake) in 2010 when oyster and $A$. modestus abundance were low (consumption values quoted above are given in the model data in the supplement). These trends in phytoplankton consumption rates clearly illustrate the effect these invasive species have on lower level trophic activities in the bight.

Of interest is also the increase in the NPP efficiency, which is the fraction of NPP directly consumed by herbivores. This index increased from $57 \%$ in 1995 (Baird et al. 2004a) to about $98 \%$ in 2007, and then declined again to $59 \%$ in 2010 (Table 1). One reason for the high NPP efficiency in 2007 is the magnitude of oyster consumption of about $90 \%$ of the in situ phytoplankton production, while it was much lower in 2010 when oyster biomass was low. Invasive suspension feeders elsewhere have been noted, for example by Alpine \& Cloern (1992), who reported that the invasive clam Potamocorbula amurensis removed a considerable amount of phytoplankton from San Francisco Bay due to heavy grazing, while Miehls et al. (2009) also noted a negative influence of the suspension feeding zebra mussel in Lake Oneida on phyto- and zooplankton, likely due to direct consumption and to competition for phytoplankton, respectively. The detrivory:herbivory ratio in the bight, on the other hand, declined in 2007 when herbivory exceeded detrivory (Table 1), again due to the high rates of phytoplankton consumption by oysters. When oyster biomass declined to lower levels in 2010, detrivory increased proportionally. However, the use of detritus as a food source increased by $19 \%$ between the pre-invasion (1995) and post-invasion high-abundance (2007) time periods, and continued to rise by $8 \%$ from 2007 to 2010 (Fig. 4).

The indices are considered to give some indication of system organization and function, measured by the decline in relative ascendency ratios and the AMI, while the normalized sum of the overheads $(\varphi)$ increased after the growth of the invasive populations (Table 4). These results concur with the general food web theory assumption that ascendency decreases, while the overhead increases following a perturbation (Ulanowicz 1996). In 2007 these 2 invasive species accounted for $10 \%$ of the total throughput and $20 \%$ of the heterotrophic throughput, which is by all accounts large enough to have a significant impact on the ecosystem's function. By 2010 oyster and Austrominius modestus biomass have reduced dramatically, so that their collective throughput accounted for only 0.3 and $0.5 \%$ of the total and heterotrophic throughputs, respectively. The trend in the decrease of the ascendency ratios and in the AMI, and the increase in the overheads are consistent through all 3 models, which would indicate that the invasive species had a negative impact on the flow of energy and organization of the bight ecosystem. However, the changes in these indices from 2007 to 2010 occurred during years when oyster and $A$. modestus abundance declined, so that these invasive species cannot logically be held solely responsible for the observed changes in system function and organization. Fluctuations in the dynamics of other species cannot be excluded in attempts to explain the functional changes in the bight over time, nor the possibility that the 'momentum' of the decline continued after the decrease in the abundance of the invasive species. The proliferation of oysters and $A$. modestus is, however, not the only ecological change since the 1995 model was developed. For example, the standing stock of the seagrass Zostera noltii in the intertidal region of the bight increased from 2960 $\mathrm{mgC} \mathrm{m}^{-2}$ in 1995 to $17282 \mathrm{mgC} \mathrm{m}^{-2}$ by 2010. Seagrass beds contribute to the function of tidal flats as an extended habitat for the juveniles of many species in the Wadden Sea, and seagrass beds are also considered to be indicators of ecosystem health (Polte et al. 2005, Reise \& Kohlus 2008), thus a positive development from an ecological point of view. The biomass of benthic grazers (Hydrobia ulvae and Littorina littorea) and some benthic detritus feeders (Arenicola marina, Capitellidae, Oligochaeta) increased from 1995 to 2010. Some benthic omnivores (Phyllodocidae, Carcinus maenas) increased in biomass, while others in the same trophic guild (Nereis diversicolor, Gammarus spp., small crustaceans, Nepthys spp.) declined (Table 2). The blue mussel Mytilus edulis also declined in biomass since 1995 (Table 2; Büttger et al. 2010). The construction of extended oyster reef/mussel beds provides a complex structure of refugial interspaces for settlement and protection which can support a large variety of epibenthos (Grabowski 2004). The interspaces in oyster reefs in the bight provide an alternative habitat for $M$. edulis where it is less exposed to predators and where it can exist at a reduced but more stable population size (Eschweiler\& Christensen 2011), while the oyster reefs provide the habitat and refuge for a variety of infaunal and epifaunal species (Kochmann et al. 2008, Büttger et al. 2008). 
Although there is no question that invasive species have altered coastal aquatic ecosystems, evidence that alien species have caused the extinction of native species is limited, or that they necessarily pose a threat to species diversity (Gurevitch \& Padilla 2004, Reise et al. 2006). The interplay between alien and native species in aquatic ecosystems is not easy to unravel considering the complexity of the coastal systems. Although the bight has undergone a shift in its state from 1995 to 2007 and again from 2007 to 2010, the alternate states are not necessarily 'stable'. The rather large changes in most of the system attributes (including ratio-based indices) from the SRB2 model to the SRB3 model would indicate that when invasive species are abundant and have a relatively large 'control' over energy flow in the system, the system is not necessarily more stable than before, but perhaps less fragile since most of the indices increased subsequent to invasion. When the invasive species become less abundant, it would appear that the system organization declines as evident from the decline in most of the indices. If these indices are considered important indicators of the system's development and organization, then the bight is now slightly worse off than $15 \mathrm{yr}$ ago. In the present study the complexity and dynamics of the bight ecosystem is highlighted, while the analyses of the food web of the bight over time allowed a holistic understanding of the effect invasive species on this ecosystem.

Acknowledgements. This study was conducted within the framework of the German-Dutch research project INFOWEB funded by the German Federal Ministry of Education and Research (BMBF), and the Netherlands Organisation for Scientific Research (NWO). We thank the Alfred Wegener Institute for Polar and Marine Research (AWI) for substantial support during the course of this study, and the Regional Office of the Wadden Sea National Park of SchleswigHolstein for access to their comprehensive monitoring data base on oyster and blue mussel distribution and abundance in the Sylt-Rømø Bight. D.B. thanks the AWI, the University of Stellenbosch, and the National Research Foundation of South Africa for additional support. We also thank the 3 anonymous reviewers for their most useful suggestions and comments on the original manuscript.

\section{LITERATURE CITED}

Allesina S, Bondavalli C (2004) WAND: an ecological network analysis user-friendly tool. Environ Model Softw 19:337-340

Alpine AE, Cloern JE (1992) Trophic interactions and direct physical control of phytoplankton biomass in an estuary. Limnol Oceanogr 37:946-955

Asmus R, Asmus H 1998. The role of benthic communities for the material exchange in the Sylt-Rømø Wadden Sea. In: Gätje C, Reise K (eds) The Wadden Sea ecosystem: exchange, transport, and transformation processes. Springer, Berlin, p 257-302

Asmus H, Asmus R (2011) Material exchange processes between sediment and water in coastal ecosystems and their modeling. In: Baird D, Mehta A (eds) Estuarine and coastal ecosystem modeling, Vol 9. Treatise on estuarine and coastal science. Academic Press, Waltham, p 355-382

Baird D (1998) Case studies: orientors and ecosystem properties in coastal zones. In: Müller F, Leupelt M (eds) Eco targets, goal functions, and orientors. Springer, Berlin, p 232-242

Baird D (1999) Estuaries as ecosystems: a functional and comparative analysis. In: Allanson BR, Baird D (eds) Estuaries of South Africa. Cambridge University Press, Cambridge, p 269-288

Baird D (2012) Assessment of observed and perceived changes in ecosystems over time, with special reference to the Sylt-Rømø Bight, German Wadden Sea. Estuar Coast Shelf Sci 108:144-154

Baird D, Heymans JJ (1996) Assessment of ecosystem changes in response to freshwater inflow of the Kromme River estuary, St. Francis Bay, South Africa: a network analysis approach. Water SA 22:307-318

Baird D, Ulanowicz RE (1989) The seasonal dynamics of the Chesapeake Bay ecosystem. Ecol Monogr 59:329-364

Baird D, Ulanowicz RE (1993) Comparative study on the trophic structure, cycling and ecosystem properties of four tidal estuaries. Mar Ecol Prog Ser 99:221-237

Baird D, McGlade JM, Ulanowicz RE (1991) The comparative ecology of six marine ecosystems. Philos Trans R Soc Lond B Biol Sci 333:15-29

> Baird D, Luzckovich J, Christian RR (1998) Assessment of the spatial and temporal variability in ecosystem properties of the St. Marks National Wildlife Refuge, Apalachee Bay, Florida. Estuar Coast Shelf Sci 47:329-349

> Baird D, Asmus H, Asmus R (2004a) Energy flow of a boreal intertidal ecosystem, the Sylt-Rømø Bight. Mar Ecol Prog Ser 279:45-61

> Baird D, Christian RR, Petersen C, Johnson G (2004b) Consequences of hypoxia on estuarine ecosystem function: energy diversion from consumers to microbes. Ecol Appl 14:805-822

Baird D, Asmus H, Asmus R (2007) Trophic dynamics of eight intertidal communities of the Sylt-Rømø Bight ecosystem, northern Wadden Sea. Mar Ecol Prog Ser 351:25-41

Baird D, Asmus H, Asmus R (2008) Nutrient dynamics in the Sylt-Rømø Bight ecosystem, German Wadden Sea: an ecological network analysis approach. Estuar Coast Shelf Sci 80:339-356

Baird D, Fath BC, Ulanowicz RE, Asmus H, Asmus R (2009) On the consequences of aggregation and balancing of networks on system properties derived from ecological network analysis. Ecol Modell 220:3465-3471

> Baird D, Asmus H, Asmus R (2011) Carbon, nitrogen and phosphorus dynamics in nine sub-systems of the SyltRømø Bight ecosystem, German Wadden Sea. Estuar Coast Shelf Sci 91:51-68

Baxter CV, Fauch KD, Murakami M, Chapman PL (2004) Fish invasion restructures stream and forest food webs by interrupting reciprocal prey subsidies. Ecology 85: 2656-2663

Blamey LK, Branch GM, Reaugh-Flower KE (2010) Temporal changes in kelp forest benthic communities following an invasion by the rock lobster Jasus lalandii. Afr J Mar 
Sci 32:481-490

Bodini A, Bondavalli C (2002) Towards a sustainable use of water resources: a whole-ecosystem approach using network analysis. Int J Environ Pollut 18:463-485

$>$ Box A, Martin D, Deudero S (2010) Changes in seagrass polychaete assemblages after invasion by Caulerpa racemosa var. cylindracea (Caulerpales, Chlorophyta): community structure, trophic guilds and taxonomic distinctness. Sci Mar 74:317-329

Brandt G, Wherman A, Wirtz KW (2008) Rapid invasion of Crassostrea gigas into the German Wadden Sea dominated by larval supply. J Sea Res 59:279-296

> Büttger H, Asmus H, Asmus R, Buschbaum C, Dittmann S, Nehls G (2008) Community dynamics of intertidal softbottom mussel beds over two decades. Helgol Mar Res 62:23-36

Büttger H, Witte S, Nehls G (2010) Miesmuschelmonitoring 2010 im Nationalpark Schleswig-Holsteinisches Wattenmeer. Auftrag des Landesbetrieb für Küstenschutz, Nationalpark und Meeresschutz Schleswig-Holstein. Trilateral Monitoring and Assessment Program (TMAP). Bericht an das Landesamt für den Nationalpark Schleswig-Holsteinisches Wattenmeer. Husum, p 1-38

Büttger H, Nehls G, Witte S (2011) High mortality of Pacific oysters in a cold winter in the North-Frisian Wadden Sea. Helgol Mar Res 65:525-532

> Carpenter SR, Ludwig D, Brock WA (1999) Management of eutrophication for lakes subject to potentially irreversible change. Ecol Appl 9:751-771

Christensen V (1995) Ecosystem maturity-towards quantification. Ecol Modell 77:3-32

Christensen V, Pauly D (1992) ECOPATH II — a software for balancing steady state ecosystem models and calculating network characteristics. Ecol Modell 61:169-185

Christian RR, Thomas CR (2003) Network analysis of nitrogen inputs and cycling in the Neuse River Estuary, North Carolina, USA. Estuaries 26:815-828

Christian RR, Baird D, Luczkovich J, Johnson JJ, Scharler UM, Ulanowicz RE (2005) Role of network analysis in comparative ecosystem ecology of estuaries, Chap 3. In: Belgrano A, Scharler UM, Dunne J, Ulanowicz RE (eds) Aquatic foodwebs: an ecosystem approach. Oxford University Press, Oxford, p 25-40

Crooks JA (2001) Assessing invader effects within changing ecosystems: historical and experimental perspectives on the role of exotic mussel in an urbanized lagoon. Biol Invasions 3:23-36

> Crooks JA (2002) Characterizing ecosystem-level consequences of biological invasions: the role of ecosystem engineers. Oikos 97:153-166

$>$ De Jonge VN, van Beusekom JEE (1995) Wind- and tideinduced resuspension of sediment and microphytobenthos from tidal flats in the Ems Estuary. Limnol Oceanogr 40:776-778

> Deudero S, Box A, Alós J, Arroyo NL, Marbà N (2011) Functional changes due to invasive species: food web shifts at shallow Posidonia oceanic seagrass beds colonized by the alien macroalga Caulerpa racemosa. Estuar Coast Shelf Sci 93:106-116

$>$ Diederich S (2006) High survival and growth rates of the introduced Pacific oysters may cause restrictions on habitat use by native mussels in the Wadden Sea. J Exp Mar Biol Ecol 328:211-227

> Diederich S, Nehls G, van Beusekom JEE, Reise K (2005) Introduced Pacific oysters (Crassostrea gigas) in the northern Wadden Sea: Invasion accelerated by warm summers? Helgol Mar Res 59:97-106

> Done TJ (1992) Phase shifts in coral reef communities and their ecological significance. Hydrobiologia 247:121-132

> Eschweiler N, Christensen HT (2011) Trade-off between increased survival and reduced growth for blue mussels living on Pacific oyster reefs. J Exp Mar Biol Ecol 403:90-95

Fast T, Müller A, Wilhelm A (1999) The Sylt-Rømø Bight Ecosystem model (SRB Model): an introduction. GKSS 99/E/28 GKSS Forschungszentrum, Geesthacht

Fath BD, Borret SR (2006) A Matlab ${ }^{\circledR}$ function for network environ analysis. Environ Model Softw 21:375-405

Fath BD, Patten BC (1999) Review of the foundations of network environ analysis. Ecosystems 2:167-179

> Fath BD, Jørgensen SE, Patten BC, Str skraba M (2004) Ecosystem growth and development. Biosystems 77 : 213-228

Fath BD, Scharler UM, Ulanowicz RE, Hannon B (2007) Ecological network analysis: network construction. Ecol Modell 208:49-55

Finn JT (1976) Measures of ecosystem structure and function derived from analysis of flows. J Theor Biol 56: 363-380

Gätje C, Reise K (1998) Ökosystem Wattenmeer-Austausch, Transport- und Stoffumwandlungsprozesse. SpringerVerlag, Berlin

> Grabowski JH (2004) Habitat complexity disrupts predator-prey interactions but not the trophic cascade on oyster reefs. Ecology 85:995-1004

Grosholz ED (2002) Ecological consequences of coastal invasions. Trends Ecol Evol 17:22-27

Gurevitch J, Padilla DK (2004) Are invasive species a major cause of extinction? Trends Ecol Evol 19:470-474

Hannon B (1973) The structure of ecosystems. J Theor Biol 41:535-546

Hare SR, Mantus NJ (2000) Empirical evidence for North Pacific regime shifts in 1997 and 1989. Prog Oceanogr 47: 103-145

Jørgensen SE, Fath BD (2004) Application of thermodynamic principles in ecology. Ecol Complex 1:267-280

Kaufman AG, Borrett SR (2010) Ecosystem network analysis indicators are generally robust to parameter uncertainty in a phosphorus model of Lake Sidney Lanier, USA. Ecol Modell 221:1230-1238

Kay JJ, Graham LA, Ulanowicz RE (1989) A detailed guide to network analysis. In: WulffF, Field JG, Mann KH (eds) Network analysis in marine ecology: methods and applications. Coastal and Estuarine Studies 32, Springer-Verlag, Heidelberg, p 15-61

Knowlton N (1992) Thresholds and multiple stable states in coral reef community dynamics. Am Zool 32:674-682

Kochmann J, Buschbaum C, Volkenborn N, Reise K (2008) Shift from native mussels to alien oysters: differential effects of ecosystem engineers. J Exp Mar Biol Ecol 364: $1-10$

> Mack RN, Simberloff D, Lonsdale WM, Evans H, Clout M, Bazzaz FA (2000) Biotic invasions: causes, epidemiology, global consequences, and control. Ecol Appl 10:689-710

Mann KH, Field JG, Wulff F (1989) Network analysis in marine ecology: an assessment. In: Wulff F, Field JG, Mann KH (eds) Network analysis in marine ecology: methods and applications. Coastal and Estuarine Studies 32, Springer-Verlag, Heidelberg, p 259-282

Martens P (2007a) Abundance of zooplankton at time series List Reede in 1995. Alfred Wegener Institute for Polar 
and Marine Research, Wadden Sea Station Sylt. doi: 10.1594/PANGAEA.646276

Martens P (2007b) Abundance of zooplankton at time series List Reede in 2005. Alfred Wegener Institute for Polar and Marine Research, Wadden Sea Station Sylt. doi: 10.1594/PANGAEA.646286

Martens P (2007C) Abundance of zooplankton at time series List Reede in 2006. Alfred Wegener Institute for Polar and Marine Research, Wadden Sea Station Sylt. doi: 10.1594/PANGAEA.646287

Martens P (2010a) Abundance of zooplankton at time series List Reede in 2007. Alfred Wegener Institute for Polar and Marine Research, Wadden Sea Station Sylt. doi: 10.1594/PANGAEA.756061

Martens P (2010b) Abundance of zooplankton at time series List Reede in 2008. Alfred Wegener Institute for Polar and Marine Research, Wadden Sea Station Sylt. doi: 10.1594/PANGAEA.756062

Martens P (2010c) Abundance of zooplankton at time series List Reede in 2009. Alfred Wegener Institute for Polar and Marine Research, Wadden Sea Station Sylt. doi: 10.1594/PANGAEA.756063

Martens P (2011) Abundance of zooplankton at time series List Reede in 2010. Alfred Wegener Institute for Polar and Marine Research, Wadden Sea Station Sylt. doi: 10.1594/PANGAEA.758182

Martens P, van Beusekom JEE (2008) Zooplankton response to a warmer northern Wadden Sea. Helgol Mar Res 62: 67-75

McCook LJ (1999) Macroalgae, nutrients and phase shifts on coral reefs: scientific issues and management consequences for the Great Barrier Reef. Coral Reefs 18: 357-367

McLusky DS (1989) The estuarine ecosystem. Blackie, Glasgow

- Menge BA (1995) Indirect effects in marine rocky intertidal interaction webs: patterns and importance. Ecol Monogr 65:21-74

Miehls ALJ, Mason DM, Frank KA, Krause AE, Peacor SD, Taylor WW (2009) Invasive species impacts on ecosystem structure and function: a comparison of Oneida Lake, New York, USA, before and after zebra mussel invasion. Ecol Modell 220:3194-3209

Nehls G, Diederich S, Thieltges DW, Strasser M (2006) Wadden Sea mussel beds invaded by oysters and slipper limpets: Competition or climate control? Helgol Mar Res 60:135-143

Nichols KH, Hoyle JA, Johannsson OE, Dermott R (2011) A biological regime shift in the Bay of Quinte (Lake Ontario) associated with the establishment of invasive dreissinid mussels. J Gt Lakes Res 37:310-317

Polte P, Schanz A, Asmus H (2005) The contribution of seagrass (Zostera noltii) cover to the function of tidal flats as a juvenile habitat for dominant, mobil epibenthos in the Wadden Sea. Mar Biol 147:813-822

Reise K (1998) Pacific oysters invade mussel beds in the European Wadden Sea. Senckenbergia marit 28:167-175

Reise K, Kohlus J (2008) Seagrass recovery in the northern Wadden Sea? Helgol Mar Res 62:77-84

Reise K, van Beusekom JEE (2008) Interactive effects of

Editorial responsibility: Christine Paetzold,

Oldendorf/Luhe, Germany global and regional change on a coastal ecosystem. Helgol Mar Res 62:85-91

Reise K, Gollasch S, Wolff WJ (1998) Introduced marine species of North Sea coasts. Helgol Meersunters 52:219-234

> Reise K, Olenin S, Thieltges DW (2006) Are aliens threatening European aquatic coastal ecosystems? Helgol Mar Res 60:77-83

Rick HJ, Rick S, Tillman U, Brockmann U, Gartner U, Dorselen C, Südermann J (2006) Primary productivity in the Germa n Bight. Estuaries Coasts 29:4-23

Scharler UM, Baird D (2005) A comparison of selected ecosystem attributes of three South African estuaries with different freshwater inflow regimes, using network analysis. J Mar Syst 56:283-308

Scheffer M, Rinaldi S, Gragnani A, Mur LR, Van Nes EH (1997) On the dominance of filamentous cyanobacteria in shallow, turbid lakes. Ecology 78:272-282

Scheffer M, Carpenter S, Foley JA, Folke C, Walker B (2001) Catastrophic shifts in ecosystems. Nature 413:591-596

> Shannon LJ, Field JG, Moloney CL (2004) Simulating anchovy-sardine regime shifts in the southern Benguela ecosystem. Ecol Modell 172:269-281

Stachowicz JJ, Byrnes JE (2006) Species diversity, invasion success, and ecosystem functioning: disentangling the influence of resource competition, facilitation, and extrinsic factors. Mar Ecol Prog Ser 311:251-262

- Stewart TW, Haynes JM (1994) Benthic macroinvertebrate communities of southwestern Lake Ontario following invasion of Dreissena. J Gt Lakes Res 20:479-493

Szyrmer J, Ulanowicz RE (1987) Total flows in ecosystems. Ecol Modell 35:123-136

Ulanowicz RE (1986) Growth and development: ecosystem phenomenology. Springer-Verlag, New York, NY, p 1-203

Ulanowicz RE (1996) Trophic flow networks as indicators of ecosystem stress. In: Polis GA, Winemiller KO (eds) Food webs: integration of patterns and dynamics. Chapman \& Hall, New York, NY, p 358-368

> Ulanowicz RE (2004) Quantitative methods for ecological network analysis. Comput Biol Chem 28:321-339

- Ulanowicz RE, Kay JJ (1991) A package for the analysis of ecosystem flow networks. Environ Softw 6:131-142

Ulanowicz RE, Norden JS (1990) Symmetrical overhead in flow networks. Int J Syst Sci 21:429-437

Ulanowicz RE, Puccia CJ (1990) Mixed trophic impacts in ecosystems. Coenoses 5:7-16

> Vitousek PM, Walker LR, Whiteaker LD, Mueller-Dombois D, Matson PA (1987) Biological invasion by Myrica faya alters ecosystem development in Hawaii. Science 238: 802-804

> Witte S, Buschbaum C, van Beusekom JEE, Reise K (2010) Does climate warming explain why an introduced barnacle finally takes over after a lag of more than 50 years? Biol Invasions 12:3579-3589

Wulff F, Field JG, Mann KH (eds) (1989) Network analysis in marine ecology: methods and applications. Coastal and Estuarine Studies 32, Springer-Verlag, Heidelberg, p $1-284$

Zaiko A, Lehtiniemi M, Narš ius A, Olenin S (2011) Assessment of bioinvasion impacts on a regional scale: a comparative approach. Biol Invasions 13:1739-1765

Submitted: December 16, 2011; Accepted: May 21, 2012

Proofs received from author(s): August 6, 2012 